\title{
The Bureaucratization of Land Tenure
}

\section{Introduction}

How did colonial empires engage preexisting forms of land tenure and seek to influence them for their own, mainly fiscal, purposes? This question is crucial for anyone seeking to understand how empires promoted settlement policies, attempted land confiscation, and developed tools of governance to extract revenues. The question is crucial also for the historian of law, because property relations stand at the intersection of several legal domains, such as the law of contract, inheritance, and family law. Discerning how rights of land tenure were attested, secured, and defended can therefore illuminate changes and continuities in the legal culture of those Muslim communities that became subjects of a non-Islamic government in Central Asia. This chapter aims to explore the ways in which imperial statutory laws and Russian bureaucratic practices transformed property relations among Muslims in the GovernorshipGeneral of Turkestan, and the ways in which they did not. This chapter will focus on how Central Asians engaged the colonial property regime as a way of acquiring landed estates that once belonged to the treasury of the khanates. At the same time, I hope to show how colonial bureaucratic practices brought about a new, more exclusive, process of textualization of forms of land tenure. This process led to the Muslims' articulation of a narrower understanding of property.

How do we approach most usefully the study of property relations and land rights as they were expressed in a cultural domain where Russian legal and administrative practices mixed with Islamic juristic thinking and established fiscal customs? This is a particularly complex question, because most of the sources suggest that the colonization aimed at the preservation of the status quo in order to avoid discontent and therefore often claimed to have left in place existing patterns of land tenure. Several Russian officials attempted to decipher the legal and fiscal attributes of land-ownership in Turkestan with a view to securing the compliance of established practices of land tenure with new fiscal policies. ${ }^{1}$ Others, by contrast, advocated a complete overhaul of such practices. Whether cautious with traditions or sympathetic to profound

1 B. Penati, "Notes on the Birth of Russian Turkestan's Fiscal System: A View from the Fergana Oblast'." JESHO 53/5 (2010): 679-711. 
reform, Russians did not operate alone. Colonial subjects played a crucial role as cultural brokers. As we shall see in detail, local scholars who were endowed with privileged knowledge of property relations were instrumental in shaping perceptions and reasoning among Russians. The available information suggests that we are dealing here with a typical colonial situation of cultural imbrications in which innovations were often formulated in vernacular languages (Persian and Chaghatay), using a vocabulary peppered with conventional and formulaic expressions derived from the specialized terminology of Islamic law. Disentangling meanings, notions, and perceptions about land rights requires that we clarify the principles and the wide array of social practices that determined the forms of land tenure in the period before the Russian conquest.

There has been substantial scholarship on this subject over the last two decades. In the growing body of literature dealing with landholding in Islamic Central Asia, however, one can discern a problem of method that keeps us from acquiring a clearer picture of precolonial property relations. First, scholarship on landholding has relied heavily on what are usually termed "documentary sources" without a firm grasp of the culture of documentation that informed the production of such sources. Most scholars have thus read "documents" as if they could speak for themselves, thereby avoiding the interpretive problems necessarily posed by eliciting meaning from these sources. It is naïve to approach texts without exploring the conceptual repertoire and the social context shaping their production. This approach to "documentary sources" is best exemplified in catalogues and calendars of legal texts that have been produced since the Soviet period and often include glaring misinterpretations. ${ }^{2}$ This observation does not necessarily mean that such repertoires are useless. Most historians have, however, adopted a "lexical" approach to their materials-assuming, that is, that there is a consistent logical equivalence between words and things and that terms appearing in one source carry the same force in another. They have thus overlooked how meaning inheres in context. Consequently, the taxonomies of property relations that we find reflected in the glossaries of catalogues merely repeat each other, in spite of the possibility that meanings might well have changed over time or that the social circumstances behind the production of texts described therein might

2 Katalog Khivinskikh kaziiskikh dokumentov (XIX-nach. XX vv.), ed. A. Urunbaev et al. (Tashkent and Tokyo: Department of Islamic Area Studies, 2001); E. Karimov, Regesty kaziiskikh dokumentov $i$ khanskikh iarlikov Khivinskogo khanstva XVII-nachala XX v. (Tashkent: Fan, 2007); B. Kazakov, Bukharan Documents: The Collection in the District Library, Bukhara, trans. J. Paul (Berlin: Klaus Schwarz, 2001). 
be completely different. ${ }^{3}$ We should keep this in mind as we attempt to read legal deeds alongside juristic tracts.

Second, studies on agrarian history tend to confer great epistemological authority on documentary sources because of their presumed implicit proximity to reality. These studies seem to have neglected that royal warrants, diplomas, and legal deeds are, in fact, written in a formulaic language that tends, as we shall see, to be conservative and does not reflect changes in the domain of legal and fiscal reasoning. Assuming that such texts provide unmediated access to the past, scholars have trivialized the possibility that information on evolving landholding patterns might be reflected better in other sources such as juristic treatises or narrative sources. It is to the latter that I want to turn in this chapter. My source basis comes primarily from the Bukharan emirate (eighteenth and nineteenth centuries). When Russians subjugated Transoxiana, they thought that practices of land tenure in the emirate reflected broader patterns at work in Central Asia. ${ }^{4}$ To study precolonial Bukharan juristic sources on land tenure is therefore the key to grasping what Russians understood (or thought they understood) as eminently "indigenous" and "traditional" in the field of agrarian relations.

Third, most of the sources that are usually examined to illustrate the situation before the Russian conquest actually refer to the post-186o period and thus speak various idioms. ${ }^{5}$ We must often rely on texts produced in Russian, written by military officials, administrators, and Orientalists, which are reminiscent of Islamic legal scholarship and interweave vernacular bureaucratese, though they do not always make their points of reference explicit. (I will discuss this colonial textual genre in Part 2.) At the same time, elements of what appears to be a purely sharĩ $a$-derived Islamicate vocabulary as found in late

3 I draw here on Florian Schwarz, who pointed out that the limitation of catalogues lies in their not reflecting the dynamics of property relations; see his "Contested Grounds: Ambiguities and Disputes over the Legal and Fiscal Status of Land in the Manghit Emirate of Bukhara." CAS 29/1 (2010): 53 .

4 The approach of the Russians to land tenure in Central Asian was predicated on the assumption of some kind of cultural uniformity. A study by Ulfatbek Abdurasulov shows that landtenure practices differed considerably between Bukhara and Khiva; see his "Pravovaia i fiskal'naia dinamika zemlevladeniia v Khorezme (XIX-nachalo XX v.)." Vostok-Oriens 4 (2015): $3^{2-46 .}$

5 This is exemplified by A. Morrison, "Amlākdārs, Khwäjas and Mulk Land in the Zarafshan Valley after the Russian Conquest." In Explorations in the Social History of Modern Central Asia (19th-2oth Century), ed. Paolo Sartori (Leiden: Brill, 2013): 23-64. As I will show, things do not become clearer if one uses instead sources from the Timurid and Shibanid periods, such as those edited and published by Chekhovich, on the assumption that, from the Mongol conquest to Russian colonization, property relations did not change in Central Asia. 
nineteenth- and early twentieth-century Chaghatay- and Persian-language sources may, in fact, reflect forms of linguistic usage shaped by colonial regulations and bureaucratic practices. Facing the difficult task of making sense of this fabric of linguistic practices-a task attempted in many colonial contexts $^{6}$ - several scholars have failed to appreciate how the definition of land rights depended on legal as much as fiscal attributes.

This chapter consists of four parts. In the first, I review the existing scholarship in light of a major shift in the meaning of landed property rights that manifested itself more clearly in the available sources from the eighteenth and the nineteenth centuries. Indeed, the term milk was used in that period to denote the ownership of produce, not of land. The consequence of this sematic shift was that, by means of taxation, Muslim rulers received a share of the produce and thereby acquired entitlements on private estates. This led to a situation of "co-dominion" in which the ruler, the landowner and the tenant shared the usufruct of the same land. In the second part, I trace how Russian lawmakers legislated on land tenure by purporting to build on local notions of "property" (and alleged lack thereof) and that they manipulated Central Asian juristic traditions. In the third, I show that the Russians introduced a more rigid understanding of property that depended on contractual evidence, which led to a bureaucratized understanding of agrarian relations. Finally, I examine two legal cases that exemplify how Central Asians attempted to take advantage of the new situation to seize land that once belonged to the former Muslim polities of Central Asia.

Forms of Land Tenure in Bukhara Before the Russian Conquest

1.1 What Approach?

Before trying to identify the ways in which land tenure in nineteenth-century Central Asia changed under Russian rule, as well as the ways in which it was unchanged, we need to offer a brief preliminary overview of the factors determining tenure and its forms. One way to do this is to consider the taxonomical principles according to which local jurists defined the types of land and its use. This approach allows us to gain a firmer grasp of the rules that formalized the juridical status of land tenure and provides us with the tools to understand

6 B.S. Cohn, "The Command of Language and the Language of Command." In Writings on South Asian History and Society, Subaltern Studies 4, ed. R. Guha (Delhi: Oxford University Press, 1985): $276-329$. 
how such rules informed local notary practices and were therefore reflected in deeds. Undertaking this interpretive task is essential, because deeds constitute most of the sources available to us that reflect property relations. One might be tempted to call this the "juristic" approach, but I suggest that that would be mistaken. It does not take a great leap of imagination to see that the kind of juristic sources I propose to turn to are directly informed by and therefore reflect local practices and social circumstances. Juristic sources do not represent legal theory as opposed to law in action. ${ }^{7}$

Others would proceed differently. Jürgen Paul, for example, proposes that any discussion of land tenure start from the idea that land has always been, in Central Asia, a commodity, and that, if one can transfer something, it must be labeled "property." Attractively sensible, Paul's proposal is nevertheless problematic in its anachronistically liberal conception of property, which originates in the West after the French revolution. It is problematic also because it conceptualizes property relations exclusively within the narrow domain of transactions, according to which, if someone can transfer her rights on land, then this land must belong to her. This notion conflates several forms of land tenure that were regarded by locals as substantively different on account of their environmental components - whether, for example, the land was a pasture or an agricultural field — and its fiscal attributes. In fact, there existed in precolonial Central Asia a variety of juridical constructions that allowed landholders to dispose of, say, state land or mortmain as if it belonged to them. It is common among students of this region to read sources in which individuals and communities had room to operate as they saw fit with land belonging to the treasury or to charitable endowments. As we shall see, this was common to people who, by virtue of their longstanding relation to the land, secured rights of disposal that were passed from one generation to another. These people could sell, mortgage, and donate the property rights on improvements (uskūna/ sukniya) such as structures or plantations that existed on the land they tilled, whether the latter was the patrimony of the state or a charitable endowment. ${ }^{9}$

7 A diametrically opposite reading is propounded in A.K.S. Lambton, Landlord and Peasant in Persia: A Study of Land Tenure and Land Revenue Administration (London: Oxford University Press, 1953): 53 .

8 See his "Recent Monographs on the Social History of Central Asia." cas 29/1 (2010): 126.

9 T. Welsford and N. Tashev, A Catalogue of Arabic-Script Documents from the Samarqand Museum (Samarkand and Istanbul: IICAS, 2012): docs. 162, 163, 330, 345, 362. 
However, the deeds reflecting such transactions also specify that the landthat is, the soil—belonged to the treasury or an endowment. In other words, while the owner of the improvements might have changed, the lessor of this land - whether the ruler, a charitable endowment, or a landowner-did not lose his property rights by virtue of the various transactions initiated by the lessee. In order to make sense of such complex juridical constructions, it may be more useful to clarify the attributes of land-ownership and the reasons various juridical constructions were elaborated to favor the transactions allowing for the commodification of land. Discerning local understandings of property will also facilitate our task of reconstructing the meanings that colonial masters and subjects conferred on the vocabulary of property that they employed after the conquest.

To advocate, as I do, a close examination of legal material is not without risks. Chris Hann has noted that "the focus on property relations must not be restricted to the formal legal codes which play a major role in our own society, but must be broadened to include the institutional and cultural contexts within which such codes operate."10 This is an invaluable warning about the temptation to impose a normative point of view on our material and on agrarian relations, but it also poses a daunting interpretive challenge. While nineteenth-century Central Asia is one such institutional and cultural context in which formal legal codes did not exist, one also finds a wide variety of juristic treatises, legal opinions, notary manuals, and established practices that shape property relations into one coherent conceptual repertoire, that is, a system. This system articulated itself in a strongly legalistic vocabulary. Eschewing the adoption of such a vocabulary is a probing task, especially if one considers that the idiom of Islamic legal deeds (Ar. wathíqa, pl. wathäiq), which convey most land transactions, is highly formulaic and resistant to change. Taken together, however, this material actually represents a case of early-modern legalism. Despite the absence of rigid codes of law, we are dealing here with norms and normative processes that are manifestly articulated in a formalistic vocabulary.

$10 \quad$ C. Hann, "Introduction: The Embeddedness of Property." In Property Relations: Renewing the Anthropological Tradition, ed. C. Hann (Cambridge: Cambridge University Press, 2008): 7 . 


\section{Key Terms of Land Tenure}

bayt al-māl: treasury

dahyak: tax amounting conventionally to one-tenth of the harvest

mamlaka: state land

mamlūk: estate

milk: ownership of produce, i.e., usufruct

kharāj: tax amounting conventionally to one-fifth of the harvest

khāṣsa: crown land

milk-i kharājī (also mamlük-i kharājī): the treasury owns one-fifth of the

produce, while the private landowner owns one-tenth of it

milk-i 'ushri (also mamlūk-i 'ushrī): the treasury owns one-tenth of the

produce, while the private landowner owns one-fifth of it

milk-i hurr: the landowner owns the entire produce, i.e., tax-exempt

property

tankhwāh: grant of a rent

'ushr: tax amounting conventionally to one-tenth of the harvest

There are several important terms in the idiom of landholding in Islamic Central Asia, with which the reader may already be familiar. One is mamlaka (or zamin-i pādishāhì), a term usually translated as "state land." As such, mamlaka should not be confused with the private domain of the ruler (khāsșa), though there may sometimes be substantial overlap between the two." Milk denotes private ownership. Mamlaka and milk are basic legal concepts in shari ${ }^{-} a .{ }^{12}$ There are many others that are specific to the bureaucratic language of the Central Asian chancelleries; we will encounter them in this chapter. The common assumption about milk among historians of nineteenth-century Central Asia is that it refers to private land-ownership. In other words, milk has generally been understood - by myself in the past and by other scholarsin its classical sense, as denoting property rights to land. ${ }^{13}$ For the historian

11 I follow here the rendering of M.E. Subtelny, Timurids in Transition: Turko-Persian Politics and Acculturation in Medieval Iran (Leiden: Brill, 2007): 206.

12 R. McChesney, "Central Asia. XI. Economy from the Timurids until the 12th/18th Century." In EIr vol. v: 218-19.

13 A. Morrison, Russian Rule in Samarkand, 1868-1910: A Comparison with British India (Oxford: Oxford University Press, 2008): 59 and passim; P. Sartori, "Il waqf nel Turkestan 
of nineteenth- and twentieth-century Central Asia, however, such an understanding of milk is misleading. As used as early as the second half of the eighteenth century, the term instead denoted rights not to the land itself but to its proceeds. We owe this revised understanding of the term to the Soviet numismatist Elena Davidovich. First in correspondence during the late 196os with Ol'ga Chekhovich - a famous Soviet historian of agrarian relations in medieval Central Asia ${ }^{14}$ - and later in a paper delivered at the Barthold Lectures in Moscow in $1975,{ }^{15}$ Davidovich observed that, at least from the fifteenth century, ${ }^{16}$ local potentates extended their rights to private landed properties. It is unclear when, precisely, this process occurred and under what circumstances. One would be tempted to think, as Chekhovich does, of confiscation and aggressive fiscal policies as effective means of putting pressure on landowners. When Shībānī Khān, for example, conquered Herat in 1515, he divided the dominions (mamälik) of Khorasan among his three sons and deprived landowners of their revenues by introducing a tax called rasm al-sadra, which was equal to the tithe (dahyak). ${ }^{17}$

Whatever the policies of these potentates, the effects of this process were manifold. What used to be a private property-right to land (milk) was made

russo tra legislazione e pratica amministrativa coloniale." Quaderni Storici 132/3 (2009): 802; "Colonial Legislation Meets Sharî̃a: Muslims' Land Rights in Russian Turkestan." CAS 29/1 (2010): 43-6o; Penati, "Notes on the Birth of Russian Turkestan's Fiscal System: A View from the Fergana Oblast'” : 744; Morrison, "Amlākdārs, Khwājas and Mulk Land in the Zarafshan Valley after the Russian Conquest”: 3o. Here Morrison refers to Schwarz, "Contested Grounds: Ambiguities and Disputes over the Legal and Fiscal Status of Land in the Manghit Emirate of Bukhara": 35 .

14 U. Abdurasulov, "Ol'ga Chekhovich: Two Facets of a Soviet Academic." IS 48/5 (2015): 785-804.

15 E.A. Davidovich, "Feodal'nyi zemel'nyi milk v Srednei Azii XV-XVIII vv.: Sushchnost' i transformatsiia." In Formy feodal'noi zemel'noi sobstvennosti $i$ vladeniia na Blizhnem i Srednem Vostoke. Bartol'dovskie chtenia 1975 g., ed. B.G. Gafurov, G.F. Girs, and E.A. Davidovich (Moscow: Nauka, 1979): 39-62.

16 Ibid.: 50 .

17 See Ghiyās al-Dīn b. Himām al-Dīn al-Ḥusaynī, alias Khwāndamīr, Ta’īikh-i ḥabīb al-siyar fi akhbār-i afrād-i bashar, ed. J. Humā̄ī, 2nd ed. (Tehran: Khayyām, 1333/1954): 4:383. I owe this inference to a remark found in the collection of Chekhovich notes, TsGARUz, f. R-2678, op. 1, d. 531, 1. 54. On the subject of land confiscation under the Shibanids, see also R.G. Mukminova, $K$ istorii agrarnykh otnoshenii v Uzbekistane XVI v. Vakf-name (Tashkent: Fan, 1966): 40-41. For similar attempts at confiscations in the history of the Islamicate world, see B. Johansen, The Islamic Law on Land Tax and Rent: The Peasants' Loss of Property Rights as Interpreted in the Hanafite Literature of the Mamluk and Ottoman Period (London: Croom Helm, 1998). 
proportional to one's share of taxation..$^{18}$ In other words, there was a transition from a regime of property to one of usufruct, in which the meaning of "landowner" evolved into "tax farmer." This transition brought about the notion that milk land was a form of "co-dominion," by which is meant that the ruler and the landowner possessed different shares of what the land produced. ${ }^{19}$ This idea will be crucial for contextualizing the knowledge that Russian officials gathered on the subject of Central Asian forms of land tenure. We shall return to the notion of co-dominion in detail later.

Davidovich's argument that milk in the post-Timurid era denoted a form of co-dominion draws strong support from an interesting juristic source, a treatise devoted to the study of the lands subject to taxation, titled al-Risāla fi tahqī arāộ̄ al-ushrīya wa al-kharājōya, which was compiled in $1768-9 .{ }^{20}$ Its author was a Bukharan qā short treatise in Arabic and Persian in a larger compendium of Hanafi law called Jämic al-ma'mūlät. The treatise is better known under the title Risāla-yi Habibìya, which the author named for his son Habībullāh. While the work has been known to students of agrarian history since $1970,{ }^{21}$ its importance remains largely underestimated. Because the work may help us understand how legists formulated the rules that determined ownership and possession in Transoxiana a century before the Russian conquest, it is to this treatise that I now turn.

'Ibādallāh begins his account by explaining that "state land" (mamlaka) is any kind of private "estate" (mamlük) whose proprietors have died without heir. In such cases, 'Ibādallāh says, the "treasury" (bayt al-māl) subsumes these estates into state land. ${ }^{22}$ I use the word "estate" deliberately to distinguish mamlük from milk (property), which appear as distinct categories in the treatise.

The $q \bar{a} d \bar{l}$ further distinguishes estates with reference to two basic fiscal categories called 'ushr and kharāj. Private estates are thus called mamlūk-i kharāji and mamlük-i 'üshrí. Making sense of such categories requires us to remember

18 uravniav ikh prava na zemliu i rentu, Davidovich, "Feodal'nyi zemel'nyi milk v Srednei Azii XV-XVIII vv.: Sushchnost' i transformatsiia”: 50 .

19 Ibid.: 44.

20 This text exists in two manuscripts in Tashkent, TsVRUz, no. 6196/II and 4976/III.

21 M.A. Abduraimov, Ocherki agrarnykh otnoshenii v Bukharskom khanstve (Tashkent: Fan, 1970): 8. See also SVR XI: 307-8. The entry devoted to a description of the Risāla refers to unpublished translations produced by two other Soviet Orientalists, A. Vil'danova and A. Javonmardiev (in Russian and Uzbek, respectively).

22 arāậi-yi mamlaka ān-ast ki... mālik-i ān fawt shuda wa az way wārithī nay mānda wa bayt al-māl shuda ast wa mamlaka haqq-i 'àmma-yi musliminn gardīda ast. 
a basic rule that our author has tacitly followed while compiling his treatise: the sultan extracts $30 \%$ from the yield produced on state land, ${ }^{23}$ leaving the remainder to the landholder. The taxes generated are further divided into three parts: one-third of the taxation is called 'ushr, the remaining two-thirds kharäj. ${ }^{24}$ The kharāj is thus twice the size of the 'ushr. It follows that 'ushr is one-tenth of the entire produce, while kharäj is one-fifth, calculated on the entire harvest. These are conventional calculations that, however, informed the compilation of the Risāla-yi Habibìya and that are useful to keep in mind as we read the treatise and review the colonial documentation. An interesting addition to the category of 'ushrī estates is when:

Upon order of the Islamic ruler someone brings to life [ihy $\left.\vec{a}^{3}\right]$ land left fallow without proprietor [zamin-i mayta bilà mälik] and turned into state land and cultivates it with 'ushrī water; this land becomes an 'ushrì [estate], according to the doctrine of Imām Muhammad [Shaybānī]. But, according to the doctrine of Abū Yūsuf (peace be upon him!), it becomes ushrī only if the surrounding estates consist of land left fallow without a proprietor; if the lands around it are kharāji, this fallow land without proprietor will become kharāji after being brought to life. According to the doctrine of the Imām Abū Yūsuf (peace be upon him!), this land, by virtue of its restoration upon order of the Islamic ruler becomes the private property $[\mathrm{milk}]$ of that person from whom the Islamic ruler takes the tithe $[\ldots]$ and gives it to his partners, who are the commons. Until the day of resurrection, this land, after the death of these conquerors, remains among their heirs or by virtue of sale will belong to someone else [ $b a-$ sabab-i bay'i ìshān ba-dìgarì 'àyid shuda].

Although this reasoning may sound convoluted and abstruse, we shall see that it shaped the approach to the systematization of local forms of land tenure taken by several Russian officials.

'Ibādallāh is equally conventional in his account of the Islamic theory of land-ownership. The true innovation of the Risäla-yi Habībìya, however, is in its elaboration of a supplementary category of land tenure. This category involves state land that the Islamic ruler (pädishāh-i Islām) sells in exchange for a Qur'ān. In this symbolic transaction, the purchaser acquires the tithe ('ushr)

23 In nineteenth-century Bukhara, there were cases in which the state levied 40\%; see O.D. Chekhovich, "O razmere kheradzha v Bukhare XIX veka." oNU (1961/3): 38-44.

24 C. Cahen, “Kharādj,” EI2 vol. IV: 1031. 
levied on that land. ${ }^{25}$ There is a simple juristic principle underpinning this procedure: the ruler disposes of all the state land as an administrator (mutawalli-yi 'amma) and is therefore entitled to receive a management fee equivalent to the tithe. By acting in this capacity, he has the power to sell this fee, ${ }^{26}$ while he should use the kharäj to the benefit of all Muslims. Consequently, by virtue of this sale, the purchaser becomes the proprietor of the 'ushr, ${ }^{27}$ while, at the same time, he should pay to the ruler the kharāj levied from his estate. ${ }^{28}$ We observe in this context a major semantic shift in milk from land to proceeds. It is here that is articulated most clearly the idea that milk denotes ownership of a share of taxation. ${ }^{29}$

'Ibādallāh states that this transaction between the ruler and his subject underlies another form of land tenure, called conventionally milk-i hurr: the landowner who purchased state land from the ruler could sell back to the latter two-thirds (thulthān) of the estate in return for the rent equivalent to the kharāj levied on the "remaining third part" of the estate (thulth-i bāqù). With the first transaction the landowner acquired the property of the 'ushr. By this sale, the landowner would now obtain also the kharäj of the produce originating from the estate. Consequently, his property would be called hurr, i.e. "freed" from the payment of the two types of taxation..$^{30}$ Florian Schwarz has argued that this procedure may not, in fact, have produced full fiscal exemption. ${ }^{31}$ Instead, he proposes that the land was merely kharäj-exempt, and the owner would still have had to pay the 'ushr. This reading overlooks the fact that the creation of milk-i hurr land consisted of two transactions. In the first, the landowner purchased a plot of land from the state: this land was liable for kharäj though exempted from 'ushr. In the second transaction, the landowner sold back two-thirds of the newly purchased estate in exchange for exemption from kharāj on the remaining third. The result was that the landowner now

\footnotetext{
25 hisșsa-yi 'ushr-i ān mamlūk mushtarī mīshawad, in Risāla-yi Habībīya, Ms Tashkent, TsVRUz, no. 6196/II: fol. 262a.

26 ḥaqq al-tawlīya-yi khwud rā ki 'ushr-i ān wilāyat-i bay' dārad, ibid.

27 'ushr-i ãn ta'alluq ba-mushtarī wa milk-i way shuda ast, ibid.

28 kharāj-i ānrā az barāy-i 'āmma az mushtarīyi madhkūr mīgīrad, ibid.

29 Davidovich, "Feodal'nyi zemel'nyi milk v Srednei Azii XV-XVIII vv.: Sushchnost' i transformatsiia": 43 .

3o wa agar mìān-i pādishāh-i Islām wa mushtarīyi madhkūr mubādala wāqi shawad bar wajh ki thulthān-i ìn arạ̄̂̄ rā mushtarīyi madhkūr bar badal-i kharāj-i thulth-i bāqī ba-pādishāh-i Islām ba-dahad ma' qabūlihi ìn thulth-i bāqì milk-i ḥurr-i khāliṣ az kharāj wa ushr shawad, Risāla-yi Habībìya, ms Tashkent, TsVRUz, no. 6196/II: fol. 262a.

31 See his "Contested Grounds: Ambiguities and Disputes over the Legal and Fiscal Status of Land in the Manghit Emirate of Bukhara": 36.
} 
owned a plot of land the produce of which was exempt from both 'ushr and kharajj. ${ }^{32}$ The jurist thereby formalized a form of fictional exchange allowing the landowner to purchase from the state a complete fiscal exemption that would allow him to receive three-tenths of the produce generated by the land he possessed. ${ }^{33}$

\subsection{The Semantic Shift of Milk}

The creation of milk-i hurr is reflected in many deeds dating back at least to the second half of the fifteenth century, which have been the subject of extensive commentary. ${ }^{34}$ Elena Davidovich, ${ }^{35}$ in particular, has reached the revealing conclusion that I anticipated above: non-tax-exempt milk, which is called, in the Risāla-yi Habībìya, mamlūk-i kharājī, is a form of "co-dominion"36 between

32 Risāla-yi Habībīya, ms Tashkent, TsVRUz, no. 6196/ıI: fol. 265a.

33 On this point, see also Davidovich, "Feodal'nyi zemel'nyi milk v Srednei Azii XV-XVIII vv.: Sushchnost' i transformatsiia”: 41; Subtelny, Timurids in Transition: 222.

34 Dokumenty k istorii agrarnykh otnoshenii v Bukharskom khanstve, vol. 1, Akty feodal'noi sobstvennosti na zemliu XVII-XIX vv., ed. O.D. Chekhovich (Tashkent: Fan, 1954): xix. Subtelny notes that there are templates for the compilation of such deeds in fifteenthcentury formulary manuals: Timurids in Transition: 222. See also Morrison, Russian Rule in Samarkand, 1868-1910: A Comparison with British India: 99; Schwarz, "Contested Grounds: Ambiguities and Disputes over the Legal and Fiscal Status of Land in the Manghit Emirate of Bukhara": 35 .

35 See her "Feodal'nyi zemel'nyi milk v Srednei Azii XV-XVIII vv.: Sushchnost' i transformatsiia."

36 The publication in which she first used this expression is "Usilenie feodal'noi razdroblennosti. Zhizn' tadzhikov v Bukharskom khanstve v XVII i pervoi polovine XVIII v." In Istoriia tadzhikskogo naroda, vol. 2, Pozdnyi feodalizm (XVII v.-1917 g.), ed. B.I. Iskandarov and A.M. Mukhtarov (Moscow: Nauka, 1964): 37. Jürgen Paul has characterized Davidovich's idea of co-dominion as "her own construction" because "she does not produce evidence in Central Asian Muslim legal thinking about such a thing." He also suggested that "it could be said that she is overextending her evidence on a particular point", "Recent Monographs on the Social History of Central Asia": 126. Paul is correct in noting that Davidovich never mentioned the Risāla in her work. Nor does Ol'ga Chekhovich make use of it in her various studies in the subject, though she translated excerpts of it in 1963. It is unclear why scholars have not profited from this source as one would expect, as many deeds, which Chekhovich had published, belong to the eighteenth century, precisely the period in which the Risâla was composed. Chekhovich and Davidovich's purposeful decision not to deal with the treatise must have depended on rivalries among academics in Uzbekistan working in the field of agrarian history and claiming an intellectual monopoly of some sort over specific topics and sources. It is clear, for example, that, already by the end of the 196os, Elena Davidovich was encouraging her colleague Chekhovich to produce a magnum opus on the subject of milk. If ever Chekhovich had made plans for such a 
the ruler and the landowner, who co-own the produce of a certain land. Her work shows that, while the landowner and the ruler divided among themselves a share (about $30 \%$ ) of the produce originating from a certain estate, they disposed of the same land as an undivided estate. This is easy to prove, so to speak. The legal procedure leading to the creation of milk-i hurr, whereby a landowner acquires from the ruler a tax-exempt piece of land, consists of a separation of estates between the ruler and the landowner, which originally constituted a larger undivided dominion. This is illustrated in the deeds notarized by qū $\bar{d} \bar{s}$, which describe the "boundaries" (mahdūdāt) of the internal divisions that are drawn during the notarization of the transaction. ${ }^{37}$ The very act of dividing the estate suggests that, before the application of this procedure, the land was not divided between ruler and landowner-hence the idea of co-dominion. But even if one were to neglect the importance of the Risāla, the evidence from legal deeds is overwhelming. We have already mentioned documents reflecting the creation of milk-i hurr. One should also read closely the more everyday sale deeds. The conservative character of the Islamic law of contract notwithstanding, deeds notarized in Bukhara are unique in specifying land-ownership as milk-i kharajji. ${ }^{38}$ This qualification suggests that the property rights of the seller and the purchaser were implicitly determined and therefore constrained by those of the ruler (milk-i 'ushrì).

A second aspect that we must consider in order to appreciate the originality of Davidovich's approach is that the ruler enjoyed rights to private estates, which he could transfer to a third party. ${ }^{39}$ Of course, one could qualify these rights as eminently fiscal, amounting to a share of the rent produced by the land equivalent to the kharāj. If so, we should also recognize the fact that, as the Risāla-yi Habibiya explains, the person who possessed a private estate owned in fact only a share of the rent equivalent to the 'ushr. This is well illustrated in the following example:

publication, they must have been jeopardized by Abduraimov's Ocherki agrarnykh otnosheniiv Bukharskom khanstve. In the margins of Chekhovich's personal copy of this work, we find several notes in which she accused Abduraimov of having plagiarized her and Davidovich's work: (doslovnoe moe; eto zhe Davidovich!).

37 “Feodal'nyi zemel'nyi milk v Srednei Azii XV-XVIII vv.: Sushchnost' i transformatsiia”: 49; Dokumenty k istorii agrarnykh otnoshenii v Bukharskom khanstve, vol. 1: docs. 11, 12, 18, $19,21,25$.

38 Welsford and Tashev, A Catalogue of Arabic-Script Documents from the Samarqand Museum: docs. 34, 68, 97, 161, 162, 248b.ii, 254, 259, 260, 262, 264, 266, 267, 312, 327, 331, 344, $346,354,369,376$.

"Feodal'nyi zemel'nyi milk v Srednei Azii XV-XVIII vv.: Sushchnost' i transformatsiia": 47. 
He [is the Lord]. An eminent ruling prescribed that the tithe [dahyak ${ }^{40}$ of the locality of Tābān would be the property of Muhammad Zamān Khwāja, [while the locality itself] would become a tax-farming grant [tankhwāh] of Walad-i Jaq Jaq. The latter has died, and we have now bestowed the locality as a tax-farming grant on the aforementioned [Muhammad Zamān Khwāja]. Let the officeholders of the chancellery take notice of this [change] in the register [daftar] and let them not overlook [this royal order]. Year 1036 [1626-27] Imāmqulī Bahādur Khān. ${ }^{41}$

The deed - a royal warrant issued by the chancellery of the Bukharan emiratesuggests that Muhammad Zamān Khwāja possessed a private estate (milk/ mamlük-i kharajjì) by virtue of his owning one-tenth of the taxation..$^{42}$ It likewise shows that the ruler could grant his own fiscal rights, that is milk-i 'ushri, to the same land first to other individuals.

One might observe that to regard milk as a form of co-dominion is to apply a narrow understanding of property that is contingent on the notion of fiscal exemption. I would object to this because, if a private landed property (such as the estate belonging to Muhammad Zamān Khwāja) could be made a grant (tankhwāh) and consequently transferred to a tax farmer, this constitutes a meaningful transformation in the local understanding of property. ${ }^{43}$ At the center of this semantic shift lies the idea that land (arādī) can be exchanged

40 On dahyak meaning "tithe" and as a synonym of 'ushr, see Risāla-yi Habībīya, ms Tashkent, TsVRUz, no. 6196/II: fol. 268b. It was also used for a tax levied on certain land devoted to benefit charitable endowments, see TsGARUz, f. I-126, op. 1, d. 689, l. 1; M.N. Rostislavov, Ocherk vidov zemel'noi sobstvennosti $i$ pozemel'nyi vopros $v$ Turkestanskom krae (St. Petersburg: Tip. Brat. Panteleevykh, 1879): 336; Dokumenty k istorii agrarnykh otnoshenii $v$ Bukharskom khanstve: 240 fn. 114; M.A. Abduraimov, "O nekotorykh kategoriiakh feodal'nogo zemlevladeniia i polozhenii krest'ian v Bukharskom khanstve v XVI-nachale XIX veka." ONU (1963/7): 36; Schwarz, "Contested Grounds: Ambiguities and Disputes over the Legal and Fiscal Status of Land in the Manghit Emirate of Bukhara": 35.

Dokumenty k istorii agrarnykh otnoshenii v Bukharskom khanstve: 13 (doc. 4). More references can be found in "Feodal'nyi zemel'nyi milk v Srednei Azii Xv-Xviı vv.: Sushchnost' i transformatsiia": 47-48.

This formulation is in accordance with the notions articulated, two centuries later, in the Risāla.

43 The complexity of overlapping meanings of property is also the basis of conflicts between landowners (milkdār) and tarkhān grantees, which flared up every time the latter prevented the former from obtaining their share of revenues. TsGARUz, f. I-126, op. 1, d. $759,11.4,5$. 
for taxation (bar badal-i kharāj/dar 'awad-i kharāj)..4 Davidovich again was the first to note this semantic shift, when she suggested that 'ushr and kharäj should be regarded as rent ${ }^{45}$ rather than as taxes, because the land is only nominally occupied by the purchaser in exchange for regular payments. Most of the landowners - that is to say, the individuals who held kharajji estate in codominion with the ruler — did not live on the land, which was, instead, rented out to peasants. The following text illustrates that point:

All of us gave our plots-mulks, bought by us for money, assembled through much sacrifice-in rent to farmers, and they perform work, from the receipts they paid us out of four batmans, ${ }^{46}$ one batman, and the other three batmans they used themselves. This order (law) has existed since ancient times; none of our rulers has interfered with it, and we cultivated this land ourselves. From last year until the present, the tax-collectors [sarkär] have been using what ought to be used by us; the remainder is used by the farmers themselves, and nothing comes to us. Having lost both land and money, we have become poor. We have turned a few times with petitions to our hakkims and have received the answer that the senior governor is coming, who will return your plots, and make you happy. [...] Now you have happily come into your domain and have taken into your own hands all the affairs and hearts of us inhabitants. We turned to you about this matter, but you would not permit us and, leaving, now leave us poor people with uneasy hearts. We await this from your Excellency: that you, in cherishing us, poor folk, and showing us, the inhabitants, your love, will restore to us the ancient law and return to us our mulks, so that we may not lose our welfare and property, and we

44 See, respectively, Risāla-yi Habībīya, Ms Tashkent, IVANRUz, no. 6196/II: fol. 262a, and Dokumenty k istorii agrarnykh otnosheniiv Bukharskom khanstve: docs. 11 (p. 50), 12 (59), 18 (91), 19 (95), 21 (102), 25 (119).

45 Postepennoe preobrazovanie naloga...v rentu-nalog, po mere obrazovaniia gosudarstvennykh kategorii zemel'noi sobstvennosti i milkov v izvestnoi pozdnee forme. See Ol'ga Chekhovich's "notes on Davidovich's letters" (po pis'mam o milke E.A. Davidovich), n.d., TsGARUz, f. R-2678, op. 1, d. 531, l. 78. Davidovich wrote two letters to Chekhovich in which she addressed directly the issue of the transformation of forms of land tenure. She sent the first from Lithuania (Poselok Nida) in July 1968 and the second from Dushanbe in August 1968. See TsGARUz, f. R-2678, op. 1, d. 531, ll. 76, 77 .

46 Batman (also man/mann) was a non-standard measure of weight, which differed substantially from one region to another. 
would pray for the White Tsar and the senior governor-lord, and occupy ourselves with our own affairs. ${ }^{47}$

In this petition addressed to the Russian authorities, a group of landowners lamented that they had rented out their possessions to tenants and that, after the conquest, the tax collectors began to raise the land tax imposed by the newcomers directly from the peasants. The tax-collectors consequently deprived the landowners of the share they had been receiving since ancient times, as they put it. This example is important for our purposes because it shows that landowners did not always live on the land they owned. ${ }^{48}$ These landowners should therefore be regarded as tax farmers who, rather than considering land a commodity, were interested primarily in the extraction of its revenues. This is an important point of departure for subsequent reflections on property relations and agrarian history in the region under study.

\subsection{A New Model of Property Relations?}

The correspondence between the Bukharan chancellery and the officeholders of the emirate in the first half of the nineteenth century further attests to the changing nature of the lexicon of property relations. Letters of instruction and simple communications illustrate how the bureaucratic center of the emirate regarded milk as tax-exempt landed property alone (what legal deeds call milk-i hurr), considering everything else the patrimony of the state. In October 1813, in a missive addressed to his vizier, Muhammad Hakìm Bī Ināq, the Manghit ruler Emir Haydar (r. 1800-26) lamented that the emirate had been negligent in the survey and registration of tax-exempt properties (milkhā) and that it had become increasingly difficult to discover who were the owners. The ruler referred to the case of a certain Muhammad Amīn Khwāja, who had issued a complaint concerning the malpractice of fiscal assessors who had levied taxes from him, despite the fact that his land was, he said, tax-exempt. When the emir asked someone to verify whether his fiscal status had indeed been recorded in a register (daftar), it turned out that Muhammad Amīn Khwāja did not, in fact, enjoy any fiscal privileges. In his letter to the vizier, the emir was concerned with the possibility that other people had been infringing on state lands (zamīn-i bisyārì az musulmānān dākhil-i mamlaka shuda-st). Emir Ḥaydar had a remedy for this untenable state of affairs: no one should levy

47 I here quote from Morrison, "Amlākdārs, Khwājas and Mulk Land in the Zarafshan Valley after the Russian Conquest": 52 .

48 "Ownership did not always imply possession," McChesney, Central Asia: Foundations of Change (Princeton: Darwin Press, 1996): 59. Such was the case also with tankhwāh grantees. 
taxes on the land that Muslims have, from time immemorial, been enjoying as their property (ba-țariq-i milkìyat tașarruf karda). Fiscal assessors should, instead, tax those lands on which people had in the past paid taxes (az qadim kharāj dada bāshad az ānjā gìrand) ${ }^{49}$ In writing to his minister, the ruler had in mind a clear opposition between the estates on which taxes were due and which he regarded as state land, and anything else that was exempt from taxation and that he considered private property.

We find precisely the same distinction half a century later in a warrant that Emir Muzaffar sent to the Bukharan qā dī Muhyī al-Dīn. In his correspondence with the $q \bar{a} d \bar{c}$, the Bukharan ruler referred to a complex situation around the village of Rāst Bādanī Kāmāt, northeast of Bukhara, in what is today the district of Vobkent. The area in question included 150 tanābs of privately owned land subject to taxation (milk-i kharājī), land under a tax-farming grant (tankhwāh), and tax-exempt property. The entire village of Rāst Bādanī Kāmāt amounted to 105 tanäbs and had been granted to the proprietors of the neighboring lands subject to taxation. The village was taken back by the state and was made an asset of the treasury (ba-mamlaka talluq yāfta). After the confiscation, the emir rented out this area to the local residents at a fixed rate. He also ordered that the landowners pay a tax on the estates newly converted into state land. This is when the problems began. First, some landowners neglected the new tenancy contract ${ }^{50}$ of the residents of Rāst Bādanī Kāmāt and attempted to keep the rent for themselves. ${ }^{51}$ Other landowners paid the treasury less than stipulated. ${ }^{52}$ Things worsened when a tax collector began to operate in ignorance of the new fiscal measures. Every time the landowners, the tenants, or the local notables complained about the worsening situation, the emir instructed the $q \bar{a} d \bar{\imath}$ to make inquests (tahqīq). The chancellery of the emirate, however, ascribed little importance to the legal status of the various estates in question. Instead, it was crucial for the state primarily to distinguish whether a given area was subject to taxation and, if so, what fiscal rate was applied to it. The following warrant illuminates the pragmatic approach of the Bukharan chancellery toward the issue of property relations: for Manghit bureaucrats,

49 Maktūbāt-i Amīr Haydar ba Muḥammad Hakìm Bī, MS Tashkent, TsVRUz, no. 2120: fol. $32 b-33 a$.

5o In the Bukharan emirate, tenants and sharecroppers (muzäri ïn) could work on state land (mamlaka) on the basis of rent contracts (ijāra). See ibid.: fol. 286b [04.05.189o]. The notarization of rent contracts, however, was not required of tenants.

51 Mubarak-nāmajāt-i Amīr Muzaffar ba Qāḍ̄ Muhyī al-Dīn, Ms Tashkent, TsVRUz, no. 407: fol. unnumbered [42a].

Ibid.: [49a]. 
milk denoted tax-exempt land, while milk-i kharājī was merely another type of land generating taxable revenues. Hence, it was not referred to as property (milk) but simply as kharājit:

Let Mullā Mīr Muhyī al-Dīn, the refuge of virtue and the shelter of legal knowledge, know that Șāhịib Naẓar Āqsaqāl and 'Umar Qulī Āqsaqāl, from the locality of Rāst Badanī Kāmāt, brought to the attention of His Majesty that, in that area they have six hundred and six tanābs, [which consists of] temporarily tax-exempt land [that is now] left fallow, taxed land, and tax-exempt land [zaminn-i tankhwāh-i bāzyāft wa kharäji wa milk]. The notable Âta Bāy is the [tax] collector. [But] he has not collected taxes on the improvements and on the land according to [our] practice, that is, in the established amount. He collected too much. We hope that this [request] will be approved so that you will forbid [this behavior], amend those [practices] so that they will be lawful, and report [back to us]. 1293 $[1876] .53$

Those who owned land subject to taxation could transfer their assets at they pleased and regarded themselves as proprietors. Nothing, however, prevented the tenants from thinking the same way. By working on state land to improve it and by paying to the state a tax on the structures they erected or the plantations that they established (uskūna pulī), tenants could secure quasi-propertyrights. ${ }^{54}$ The latter, as we have noted, would ensure that tenants could bequeath to their offspring the land according to the Islamic law of inheritance, ${ }^{55}$ but they would also be able to transfer the property rights to the land's improvements to other individuals by virtue of legal transactions notarized before a $q \bar{a} d \bar{\imath}$, thereby disposing of the land as if it effectively belonged to them. With this in mind, one could expand Davidovich's argument and argue that milk in nineteenth-century Transoxiana reflected not a form of co-dominion between the ruler and the landowner but a web of property relations in which the entitlements of the ruler, the landowner, and the tenant overlapped. Of course, none of these actors regarded his entitlements to a share of the produce as a form of co-dominion. What mattered for each was to be able to dispose of a share of the produce rather than to own the land.

53 Ibid.: [122a].

54 McChesney, Central Asia: Foundations of Change: 59.

55 Welsford and Tashev, A Catalogue of Arabic-Script Documents from the Samarqand Museum: doc. 345 . 
We have considered so far a flexible system of property relations that is determined by the fiscal status of land. In this system, usufruct was the eminent attribute of tenure, which led to the creation of property rights-hence, the frequent expression "proprietary usufruct" (tașarruf-i mālikāna) in deeds. There is little doubt that, throughout the seventeenth, eighteenth, and nineteenth centuries, Central Asian jurists agreed to safeguard the integrity of such rights and regarded them as a prerogative of the tenants. Muftis issued many legal opinions showing that, upon the tacit agreement (sukūt) of a landowner, a tenant who cultivated and improved an estate could, with time, act as if he were a proprietor of the land and pass it on to his offspring. ${ }^{56}$

This was the case with the land that individuals or communities received by royal grant. The effective disposal (tasarruf ba-țariq-i milkìyat-i dhì al-yad) of such land "since time immemorial" (az qadìm al-ayyām) gave rise to property rights. One who possessed such land would thus regard it as his own (makhșuss). ${ }^{57}$ Rights to summer pastures are a particularly complex case. Usually situated on rain-watered mountain land, away from winter settlements (qishlāq) where people worked agricultural land, summer pastures were state land (mamlaka). The ruler would allow herdsmen who engaged in seasonal transhumance to use this land to feed their cattle. He could also transfer the revenues produced by such pastures to a third party - for example, a notable, or a sayyid — and thus turn it into a source of tax-farm income. ${ }^{58}$ While the legal status of summer pastures evidently prevented them from becoming private property,,$^{59}$ pastoral groups might nevertheless come to regard such land as their own property, on account of the prolonged access and rights of use they had enjoyed. Climatic instability may have made pastures attractive also for seasonal agriculture, and nomads may have erected structures such as storehouses or barns. Such groups probably attempted to infringe on the rights of the state and thus acquire

56 TsGarUz, f. I-164, op. 1, d. 13, l. 1; TsGARUz, f. R-2678, op. 2, d. 17, l. 1; TsGARUz, f. I-125, op. 1, d. 495, l. 10; Welsford and Tashev, A Catalogue of Arabic-Script Documents from the Samarqand Museum: doc. 679 .

57 See Materialy po istorii Ura-Tiube. Sbornik aktov XVII-XIXvv., ed. A. Mukhtarov (Moscow: Izdatel'stvo Vostochnoi Literatury, 1963): 49. This text is a royal warrant issued by Emir Haydar in the early nineteenth century. It confirms that a sayyid (descendant of the Prophet) has the right to dispose of water and lands in the province of Ura-Tepe as his property. The ruler also prohibited fiscal assessors from collecting taxes from such properties. See also ibid., 15 .

$5^{8}$ P.P. Ivanov, Khoziaistvo dzhuibarskikh sheikhov. K istorii zemlevladeniia v Srednei Azii v XVI-XVII vv. (Moscow and Leningrad: Izdatel'stvo Akademii Nauk ssR, 1954): 73, 75.

59 Report (doznanie), assistant of the commandant of the Samarqand Province, 23.01.1898, TsGARUz, f. I-21, op. 1, d. 475, l. 4 ob. 
ownership of such land, but, their rights to pastures were regulated by the state every year through the work of its agents. It is also clear that pastoral groups seldom felt the need to secure their rights to pastures by means of notarization. Things changed considerably with the Russians, under whose rule there was a shift from a flexible system of agrarian relations based on usufruct to one based on land-ownership attested by legal deeds.

For almost two decades, from the beginning of his tenure in 1867, von Kaufman, the first governor-general of Russian Turkestan, ruled the country on the basis of provisional statutory laws drafted by the so-called Steppe Commission. At the same time, he sought to establish a new statute that would design a land policy specifically for Turkestan. He therefore constituted several commissions that collected legal deeds and treatises in vernacular languages and attempted (so it has often been reported) to describe agrarian relations and forms of land tenure in Central Asia.

\subsection{Vernacular Knowledge and its Colonial Uses}

1869 was an important year in the history of colonial legislation on land tenure in Turkestan. The chancellery of the Governorship-General received reports from the Orientalist Aleksander Kuhn (1840-88) and Colonel Mikhail Nikitich Nikolaev indicating that there had existed, before the Russians, a complex situation in which land rights overlapped with fiscal privileges. Taking stock of this information, the chancellery advised Kaufman to establish a commission to study the agrarian question. ${ }^{60}$ At the head of this commission was Andrei Ivanovich Gomzin (d. 1885), a major general who directed the chancellery of the Governorship-General from 1869 to $1877 \cdot{ }^{61} \mathrm{He}$ was assisted by the commandants of all the provinces (oblast') and several local informants. The

\footnotetext{
6o A.P. Savitskii, Pozemel'nyi vopros $v$ Turkestane (V proektakh i zakone 1867-1886) (Tashkent: Izdatel'stvo SamGU, 1963): 15-16.

61 "A man without education but who knew very well the laws and all the possible circulars, and who was a marvelous accountant," G.P. Fedorov, "Moia sluzhba v Turkestane (18701910)." Istoricheskii Vestnik 9 (1913): 809. On Gomzin's strained relationship with General Mikhail Dimitrevich Skobelev, one of the preeminent personalities of the Russian conquest of Central Asia, see B.A. Kostin, Mikhail Dimitrovich Skobelev (Moscow: Moladaia Gvardia, 2000).
} 
reports that this commission produced were extremely important and will be instructive in our investigation. They will allow us to trace the genealogy of Russian legislation on landholding, as we see how the statutory laws promulgated in 1886 incorporated some of the notions of landholding formulated by the Gomzin commission. The Gomzin commission's reports will also help us see how the colonizers attempted to instrumentalize a purported continuity with the past.

To whom does the land belong? What do milk-i hurr mean and milk-ighayr-i hurr mean? What does waqf mean? Is the land possessed individually or communally? Does the land belong to the individuals who possess it? Do they possess under customary law or shari $a{ }^{-62}$ Judging from the nature of the questions that they posed, the members of the 1869 Gomzin commission had at least a grounding in the rudiments of landholding in Central Asia. And one or more members of the commission must have been able to review legal deeds, suggesting that they had mastered Persian. The vocabulary of tax-exempt landownership (milk-i hurr) and tax-liable land-ownership (milk-i ghayr-i hurr), for example, was used only in native-language purchase deeds in which the creation of milk-i hurr was notarized. ${ }^{63}$ This suggests that the commission had access through its local informants to Islamic juristic knowledge. Gomzin and his fellows certainly understood that acquainting themselves with the local idiom of land tenure was a key to their mission. This is clear from the three reports (doklad) that the commission submitted to the chancellery of the Governorship-General. Their notes show that, to explore the established forms of land tenure in the territories of Bukhara and Khoqand now conquered by the Russians, required tinkering with the shari $a$ and its local written traditions. The notion on which the commission structured its report was that "the basic principle of Islam, according to which the land belongs to the Muslim world, offers the possibility [...] of reducing the various regulations of sharîa on private property to one of possession and usage." 64

62 TsGARUz, f. I-1, op. 22, d. 3, l. 86.

63 Dokumenty k istorii agrarnykh otnosheniiv Bukharskom khanstve: 59, 102, 119.

64 Osnovnoe polozhenie islama, chto zemlia est' dostoianie vsego musul'manskogo mira, daet, odnako, vozmozhnost' svesti $v$ raznoobrazniia postanovleniia shariata o pravakh chastnoi sobstevnnosti k idei pol'zovaniia ili vladenia, TsGARUz, f. I-1, op. 22, d. 3, l. 101. Here the commission referred also to several important studies on Islamic law in Russian and French: Baron N.N. Tornau, Musul'manskoe pravo (St. Petersburg: Tip. Vtorogo otdeleniia sobstvennoi E.I.V. Kantseliarii, 1866); M. Perron, "La proprieté pour la loi Musulmane n'est qu une possession." In Khalil ibn Ishaq, Précis. de jurisprudence musulmane ou principes de 
In this regard [the commission reported] another reason for the incertitude of shari a [on property rights], which derives from the unquestionable principle of the state's ownership rights [articulated by] the authors and the commentators of shari $a$. The result is that the commentaries serve to distinguish among the rights of use [pol'zovanie] and defense from legal attempts of individuals [to seize the property of the state] and from illegal constraints posed by the state itself. However, among those rights that the written Muslim law ascribes to individuals and communities, it is easy to discern also those that the law denies to individuals and communities and that belong to the state. So, in the books of Abu Bakr Khwāhar-zāda and the Tafariq-i Baqqā $l^{65}$ it is written that milk$i$ hurr-i khälis are called the lands on which kharāj and țanābāna [tax per tanāb] are not levied. The lands are the property of those who possess them, who purchased them for money and relinquished a cultivated portion of them to the treasury. [The proprietors] acquired, according to royal warrants, the right to eternal disposal. Further, in explaining the method of creating milk-i hurr, the sharí'a says that everyone who wishes to turn the land that is in his possession or use into land to which he has rights of ownership and is therefore tax-exempt, he has first to purchase it for money from the ruler and, after that, to relinquish two-thirds of it to the Treasury. [In this way, he] turns one-third of it into private property and avoids paying kharāj and tanābāna on it. [...] These norms lead to two inferences: 1 ) only lands that are milk-i hurr are the property of private individuals, while the others, as they were not alienated [by the treasury], belong to the state as the owner of a votchina (ancestral landed estate); 2) a necessary attribute [priznak] of private landownership is the fiscal exemption of the land. From this one can infer that all the lands on which kharäj and 'ushr is paid are state lands. ${ }^{66}$

législation musulmane civile et religieuse selon le rite malékite, trans. M. Perron (Paris: Imprimerie Nationale, 1848-54), vol. 3: 578 fn. 18.

65 This is no doubt a corruption of the title Jämi al-tafärīa fì al-furūe, a compendium of Islamic substantive law by Muḥammad b. Abū al-Qāsim al-Baqqālī al-Khwārazmī (d. 119o). The Gomzin commission took the reference to these twelfth-century juristic authorities directly from deeds for the creation of milk-i hurr. For such deeds covering the early modern period, see, Dokumenty k istorii agrarnykh otnoshenii $v$ Bukharskom khanstve: 45 , $55,105,124,188$. Such juristic references were used also for composing similar deeds in later periods. AMIKINUz, no. 1119. Cf. Welsford and Tashev, A Catalogue of Arabic-Script Documents from the Samarqand Museum: doc. 34 . 
The members of the Gomzin commission, namely the military commandants of the various provinces, distinguished "property" (sobstvennost') rights to land from "possession" (vladenie) and "use" (pol'zovanie) and regarded the latter two categories as insufficient to determine the former. More important, the reasoning reflected in the works of the Gomzin commission is strikingly similar to that in the Risāla-yi Habibiya and in the work of Davidovich. This applies, for example, to the proposition that it was only the fiscal status of the land that determined ownership rights. In particular, it pertains to the creation of tax-exempt landed property, which required that the treasury alienate (otchuzhdenie) its rights to the land-hence the division (mahdüd) of what was in co-dominion between the ruler and the landholder. It is particularly important that the members of the commission were careful to explain that, by virtue of creation of milk-i hurr, the landowner could finally purchase land. This is reflected clearly in the Risāla and in legal deeds, where taxation is exchanged (bar badal) for land. ${ }^{67}$ But decisive proof of the commission's full acquaintance with Central Asian Islamic juristic literature comes from the treatment of land subject to taxation. The following excerpt shows that the members of the Gomzin commission regarded milk-i kharāji as "estate" (mamlūk), thereby suggesting, implicitly, an important parallel to the Risāla:

In specifying with all exactitude the rights to the lands sold by the treasury and, as such, exempted from taxation, the sharita categorizes all the other types of land in private use under one rubric: mamlūk or milk-i ghayr-i hurr. [This] means a possession that is not hurr-ikhäliṣ on account of the negative preposition ghayr. [...] Various commentators of the Muslim world disagree on the way one should determine the factual use [ fakt pol'zovaniia] that confers on the individual [some] rights to the land. All of them agree, however, that, with the termination of the factual use and the turning of their possession into fallow land [mawāt], all the rights of the individual to the land also cease. With the right to the land [...] comes also the possibility to alienate by sale or inheritance. One needs only answer the following question: does the right assigned to an individual to use fallow land lead to a termination of the right that the state had to this land? According to the rules of sharita, the land that is milki ghayr-i hurr originates either from lands that are left fallow following irrigation or in other ways. [But they are] all subject to taxation, if they are not turned into milk-i hurr-ikhälis. The right of the individual to them can always be taken away by the state, in case of fiscal evasion or in the 
absence of land use, or if the land becomes fallow again. [...] From what was said, one should infer the following: 1) The holder of milk-i ghayr-i hurr is a user but not a proprietor, even if his right of use is inheritable and transferable. 2) One who becomes the possessor of land by using it does not receive ownership rights but instead loses all rights to the land with the termination of its use. 3) Land-ownership rights belong to the state also with regard to the lands that are at someone's disposal, because the state has the power to sell these lands either to their possessor or to another individual. In this way, the basic right of the individual to milk-i ghayr-i hurr land is a right of use that originates from the irrigation of the land, which is given to another person through inheritance or sale. [...] Considering what has been said, the commission has come to the conclusion that:1) One can recognize ownership rights only to those lands that have been transferred by the state according to the principles and the stipulations determined by sharía. One should consider these lands as $[\ldots]$ under private ownership [...]; the tax is a direct consequence of the land-ownership right of the state. 2) Accordingly, no other lands have any owner [votchinnik] other than the state. Whoever occupies these lands by establishing pastures, structures, or gardens does so merely with rights of use, which are more or less defined and limited. ${ }^{68}$

The Gomzin commission was adamant in its conclusions. All the lands within the boundaries of the Governorship-General belonged to the treasury and could not be the object of transactions without the permission of the Russian government. At the same time, the plots of land that were milk-i hurr and those acquired by the Russians before the new legislation were considered private property. ${ }^{69}$ A parallel might seem to present itself here between the Gomzin commission representing the Russian government and the Bukharan Emirate under the rule of Emir Haydar: but this would be misleading. True, both used fiscal categories to define forms of land tenure, thereby classifying the land into what was exempt from taxation and what was subject to it. However, the Gomzin commission sought also the legitimation of its study of local forms of land tenure in light of the Russian imperial tradition:

This principle that it is the state that enjoys property rights to the land, which is a tenet of the Muslim legislation, belongs also to pre-Petrine Rus' and exists up to the present in the Digest of Laws [Svod Zakonov]

68 Ibid., ll. 103ob-105ob.

69 Ibid., l. 117. 
with regard to the great majority of lands of the Russian state. [This principle] never affected the enrichment of the people, nor did it hamper the improvement of the land. But leaving to the regent the means to direct the colonization [napravliat'kolonizatsiiu] [served the purpose] of defending the alien [inorodcheskoe] and often also its own Russian people from the unfortunate fate of land deprivation [obezzemleniia]. [...] Conversely, when [we] hurriedly conferred patrimonial rights [votchinnoe pravo] upon a population that was accustomed only to enjoy rights of use, [we] often brought about very bitter consequences for the same population. [It] created a few small landowner-exploiters and a mass of miserable, disadvantaged, abject [people] deprived of their land. ${ }^{70}$

It is here that we first find evidence of an attempt to instrumentalize the idea of continuity with Central Asian fiscal practices and the traditions of the Russian imperial law, but this tendency becomes even clearer in further reformulations of what the commission understood to be the local traditions of land tenure. While on the one hand, it recognized that milk-i hurr is close to the Russian notion of "ownership" (sobstvennost'), ${ }^{71}$ it firmly stated, on the other, that the notion of ownership right is completely alien to Muslim law, which is, of course, a misrepresentation. ${ }^{72}$

The idea that there existed only one form of private property in Central Asia and that the creation of such property depended on the ruler's willingness to relinquish land in exchange for taxes lent itself to certain obvious conclusions. The first was the idea that the ruler in Central Asia was necessarily a kind of Oriental despot who owned all the lands and disposed of them as he pleased. The second was the idea that all land subject to taxation should be regarded as belonging to the treasury: many Russian officials inclined to the view that lands which were, in Bukhara, labeled mamlaka and mamlük (milk-i kharājī) were part of a single domain of state land. However tempting this view, it is misleading. It is true that the state enjoyed certain rights to private estates by owning a share of the rent that was proportional to a certain amount of land. As the Risāla-yi Habībìya made clear, however, the legal category of mamlaka remained distinct from mamlūk and milk.

\footnotetext{
$70 \quad$ Ibid., l. 115 .

71 Ibid., l. 139ob.

72 Ibid., l. 138ob.
} 


\subsection{Interpreting Russian Statutory Laws}

The conflation of private estates with state land is epitomized by the Russian interpretation of the term amlāk. Originally this expression was used by the Bukharan chancellery only as a synonym of mamlaka. ${ }^{73}$ It did not convey a strictly legal meaning but primarily a fiscal one: state land under taxation. Russian administrators used it to denote every kind of land subject to taxation, regardless of the tax rate and thereby including private estates (milk-i kharājī/'ushrī $).{ }^{74}$ This idea became the gospel of the Kaufman administration, which, in 1873 and 1881, proposed two land-reform projects. Both proposals stipulated that land should be divided into three categories, each of which was purported to correspond to a concept stemming from Islamic law: 1) state land (amliak);2) tax-exempt private property (milk), and 3) land belonging to charitable endowments $(v a k f)$. These two projects shared the major assumption that "Islamic law does not, in general, contemplate the right to

73 Abduraimov, "O nekotorykh kategoriiakh feodal'nogo zemlevladeniia i polozhenii krest'ian v Bukharskom khanstve v XVI-nachale xx veka": 36 . In his Ocherk pozemel'nopodatnogo $i$ nalovogo ustroistva b. Bukharskogo khantsva (Tashkent: Izd. SredneAziatskogo Gosudarstvennogo Universiteta, 1929): 23, Aleksander Semenov suggests that amläk denoted in Bukhara only fallow land part of which the ruler assigned to the population for irrigation and from which was levied more than was paid on the "kharāj lands." Semenov does not here provide any evidence other than a reference to a personal communication, and it is unclear what he means. It is difficult to know what the hișșat al-kharāj levied from state land amounted to, because it was determined (qarār) every year.

74 N. Khanykov, Opisanie Bukharskogo khanstva (St. Petersburg: Tip. Imp. AN, 1843): 11619; Fedor K. Girs, Otchet revizuiushchego po Vysochaishemu poveleniiu, Turkestanskii krai, Tainogo Sovetnika Girsa (St. Petersburg: Senatskaia Tip., 1884): 344-5; Proekt Vsepoddaneishago otcheta General-Ad'iutanta K.P. von Kaufman po grazhdanskomu upravleniu i ustroistvu v oblastiakh Turkestanskogo General-Gubernatorstva. 7 noiabria 1867-25 marta 1881 goda (St. Petersburg: Voennaia Tip., 1885): 229-30; A.I. Shakhnazarov, Sel'skoe khoziaistvo v Turkestanskom krae (St. Petersburg: V.F. Kirshbaum, 1908): 64. In his Russian Rule in Samarkand, 1868-1910: A Comparison with British India, Morrison writes that Rostislavov "appears to be the originator of the Russian understanding that mulk and amlak refer, respectively, to private and State land, stating that they were separate legal concepts." In fact, Rostislavov, who wrote in 1874 and 1879, was a late contributor to the colonial discourse about amlāk. In January 1869, for example, Golovachev, who was military governor, asked the commandant of Tashkent to collect all the vakufnyie, amliakovye, and mul'korye deeds (i.e., deeds of waqf, amlāk, and milk lands), a fact suggesting that, by the year the Gomzin commission began its work, the notion that amläk included both mamlaka and milk-i kharāji had already circulated among the Russians in Turkestan. See TsGARUz, f. I-36, op. 1, d. 454, l. 6. 
own land $[\ldots]$ and only the sovereign has the right to allocate it."75 Both projects were met with fierce criticism by the commissions that reviewed them in St. Petersburg. One argument against them was that they aimed to introduce in Turkestan a land law that reinstated juridical categories predating the law of emancipation of state peasants issued in 1861, whereas the latter regulated that "only unpopulated lands directly owned by the treasury could be considered 'state lands."'76 Another matter of contention between the proponents of the land-reform projects and their opponents was the category of state land (amliak), as used by the Kaufman administration in a sense that went far beyond the term's fiscal meaning. The Russians used amliak as a portmanteau term that blended juridical and fiscal categories. Thus, the notion of amliak actually applied to two different legal categories of landholding, state land (mamlaka) and private estates (milk/mulk in the vernacular). At the same time, however, various fiscal categories, such as state land subject to all sorts of taxation, former crown lands (khāsșa, șulțānī, mìrī qūrūq), and private estates on which were levied a wide range of taxes, such as kharäj, 'ushr, etc., fell under the rubric of amliak. The major implication of the application of the category of amliak was that the vast majority of cultivated land on which taxes were levied should have been considered the patrimony of the Russian Empire.

Not everyone agreed with this view. In St. Petersburg, Fedor Karlovich Girs, the leader of an official senate inspection tour in Turkestan in 1882, issued a vehement critique of the land laws proposed by Kaufman and his clique. Writing in Turkestanskie Vedomosty, the official newspaper of the colonial government in Tashkent, Girs stated that "the theory of the absence of property rights in Islamic jurisprudence was a purely political invention," and he added that "exacting taxes cannot continue to be an obstacle to recognizing

75 voobshche pravo pozemel'noi sobstvennosti po musul'manskomu voprosu ne sushchestvuet [...] vozvyshaetsia verkhovnaia vlast' khana ili emira, kotoromu prinadlezhit pravo rasporiazheniia zemel'noi sobstvennost'iu strany. G.[irs F.K.], "K voprosu o zemlevadenii v Turkestanskom krae II." TV 26-29 (1885): 66-7.

76 E. Pravilova, "The Property of Empire. Islamic Law and Russian Agrarian Policy in Transcaucasia and Turkestan." Kritika 12/2 (2011): 380 . The review of the 1871 land-reform project found ample coverage in the press, which favored the Kaufman administration. The article "Po povodu proekta zemel'nogo ustroistva Turkestanskogo kraia," Golos 56 (1875), reported and commented on the main criticisms of the project. Among them: "Notoriously, the major goal of this reform [1861 emancipation] consists of turning the agricultural population of the empire into peasant-proprietors, not into possessors of state lands" (sdelat' zemledelcheskoe naselenie imperii krest'ianam-sobstvennikami, a ne obiazatel'nymi vladeltsami zemel' pravitel'stvennykh). The article appeared also in TS $15^{2}$ (n.d.): 9 . 
property rights" and that "sharìa says nothing against private ownership of land."77 Although Girs, along with the commission that reviewed the 1873 and 1881 projects, denounced the limits of the legislation on land rights as it had been formulated up to that time, central agencies in St. Petersburg were critical of his recommendation that the government should accord the indigenous population of Turkestan full ownership rights. In 1886 the State Council in St. Petersburg approved a new statute (polozhenie) that contained several measures intended to resolve the question of the legal status of lands. The statute evidently accepted most of the ideas formulated in a draft proposal on land organization (pozemel'noe ustroistvo) produced by the Ignatev commission in 1884. The statute introduced two broad categories of subjects among the "sedentary population," viz., "rural communities" (sel'skie obshchestva) and "city dwellers" (gorodskie zhitely) and provided the normative basis for the definition of landed-property relations in the following articles:

Article 255: The rural sedentary population retains a permanent and hereditary right to those lands (amliak land) that they possess, use, and dispose of [zemly, sostoiashchiia v postoiannom, potomstvennom ego vladenii, pol'zovanii i rasporiazhenii], on the basis of the rules defined by local custom.

Article 269: Land holdings assigned to urban inhabitants that are located within the confines of the city boundaries are considered the property of the individuals in question.

Ekaterina Pravilova has argued that the statute adopted in 1886 was a compromise between the view that all Central Asian land constituted state property and the view that held that the settled rural population could enjoy private property rights to land. ${ }^{78}$ Worded as it was, Article 255 stood somewhere between two polarized positions on colonization. Agencies in St. Petersburg and Tashkent were involved in a complex debate on plans about resettlement policies (kolonizatsiia) for Turkestan. Some experts, such as Girs, regarded the colonization of Central Asia as a process of integration of Turkestan into the body of the empire; they thus saw in the confirmation of land-ownership rights to Central Asian Muslims a way to help Russian settlers, when the latter finally

77 G[irs], “K voprosu o zemlevadenii v Turkestanskom krae II.”: 69, 70.

78 Pravilova, "The Property of the Empire": 380. 
acquired land. ${ }^{79}$ Others, such as Gomzin, von Kaufman, and Ignat'ev instead regarded Turkestan as the patrimony of the empire and its lands as the property of the state..$^{80}$ But the matter is more complicated. Pravilova also notes that the wording of Article 255 "described the rights of the 'settled rural population' to amliak lands as 'possession, use and disposal,' which, of course, actually corresponded to the definition of 'property' in the Russian civil code." ${ }^{81}$ Thus, she suggests, the effect of Article 255 (and its equivalent in the statute's 1901 revision) was to accord property rights to Central Asian peasants. This interpretation is problematic for several reasons, which we should now consider.

Breaking the article into its constituent elements may be useful but may also lead to glaring misinterpretations. When Article 255 was published, contemporary observers did not all read it the same way. The Russian officials who participated in the drafting of 1886 statute employed a lexicon of property relations that differed from the terse definition of property formulated in the Russian civil code. As we have seen, the tendency was to gloss the term amliak as state land. It would therefore be counterintuitive to imagine that Russian lawmakers adopted this term to denote "private property." In 1891 an article published in the Turkestanskie Vedomosty lamented that not even the shadow of the concept of property was present in Article 255 and suggested that the lawmakers had regarded the land of Turkestan as a res nullius. ${ }^{82}$ This suggests that people at that time did not read Article 255 as Pravilova does, and, in the reports of the Gomzin commission (1869), the Russian officials involved in the study of local forms of land tenure distinguished carefully the idea of property (sobstevnnost') from other notions of tenure (vladenie) and use (pol'zovanie). This attention manifests itself also in the proposal for "land organization" drafted by the Ignat'ev commission (1884), which served as the basis of the 1886 statute. ${ }^{83}$

Pravilova is correct in assuming that some contemporaries of the statute might have read "possession, use, and disposal" as the defining attributes of

79 G[irs], "K voprosu o zemlevadenii v Turkestanskom krae II”: 76; Id., "K voprosu o kolonizatsii," TV 29 (1885): 8 o.

8o Zemli Turkestanskogo kraia, za iskliucheniem sostoiashchikh na prave pol'noi sobstvennosti, ostaiutsia gosudarstvennymi; see Art. 255 of "Pozemel'noe ustroistvo Turkestanskogo kraia," vyrabotannyi komissiei grafa Ignat'eva. In Savitskii, Pozemel'nyi vopros v Turkestane: 181.

81 Pravilova, "The Property of the Empire": 381.

$82 \quad V$ zakone etom, kak vidno, o prave sobstvennosti net nikakogo nameka, A.P., "Pravo pozemel'noi sobstvennosti v Turkestanskom krae." TV 18 (1891): 70.

83 See Savitskii, Pozemel'nyi vopros v Turkestane: $181-5$. See also the comments of the Ministry of War on the proposal, ibid.: 186-95. 
property, as they were in the Russian civil code. ${ }^{84}$ However, as one Russian commentator noted in $1907,{ }^{85}$ the 1886 statute included other articles that restricted the scope of the rights accorded in Article 255 and complicated its interpretation. For example, Article 259 identified Central Asians' rights to the land as pertaining to "use" (pol'zovanie), while Article 260 specified that the locals enjoyed ownership only of plantations and structures. One is left to wonder why, if Article 255 recognized de jure property rights to land by the rural population by employing the concepts of "possession, use, and disposal," Article 269 stated that city dwellers enjoy ownership of plots of land by employing the category of "property." Evidently, the legislators attempted to preserve the attributes of and the distinction between these different notions of tenure.

Rather than superimposing onto Article 255 the idiom of the Russian civil code, it is perhaps more helpful to read the article as a whole and clarify the purposes the Russians wanted to achieve with it. The primary message conveyed was that the new government's "confirmation" (utverzhdenie) of the forms of land tenure existing among the local population accorded to local custom. Read in this light, the references to "possession, use, and disposal" and amliak land necessarily acquire a different meaning: the Russians aimed to preserve the complexity of existing land rights embedded in the term amliak and as understood by the local population. Key to understanding of the intended meaning of the article is appreciating that confirmation of rights to land would be achieved, in the legislator's view, by relying on local customs. As Beatrice Penati has suggested, Article 255 was a renvoi to Islamic law, ${ }^{86}$ but the renvoi was implicit because the article does not clarify the procedures that would be required to secure the confirmation of land rights. The notarization of legal deeds would play a crucial role. Article 261 states that transactions of land between indigenes (tuzemtsy) would be conducted according to local customs (sovershchaiutsia po sobliudaemym $v$ kazhdom meste mezhdu tuzemtsami obychaiam). At the same time, Article 235 confers on native judges the authority to notarize every type of deed and contract between locals, except for those acts that were stipulated according to the general rules of the empire. It follows that native judges, that is, qā to notarize deeds attesting to the land rights of Muslims in Russian Central

84 One of them was N. Dingel'shtedt, "Pozemel'nye nedorazumeniia v Turkestane." Vestnik Evropy 2 (1892).

85 A. Frei, "Zakon 10 iiunia 1900 i primenenie ego k bogarnym zemliam." TV 58 (1907).

86 B. Penati, "Swamps, Sorghum, and Saxauls: Marginal Lands and the Fate of Russian Turkestan." CAS 29/1 (2010): 61. 
Asia. It is unlikely that Muslim native courts would solemnize deeds of sale of land according to the definition of property in the Russian civil code. Equally, it is improbable that the legislators overlooked the fact that the Islamic legal language employed by native courts does not distinguish between possession, use, and disposal (vladenie, pol'zovanie, and rasporiazhenie). A complicating factor in assessing the implications of the renvoi to Islamic law is that harmonization between Islamic and Russian laws on issues of land tenure was apparently never a major concern for the colonial administration. While one may get a superficial impression of this by comparing the legal terminology used in the notarization of land deeds before and after the Russian conquest, ${ }^{87}$ substantive evidence comes from the Chaghatay translation of the statute. There, Article 255 is rendered without reference to the notion of amliak:

[The government confirms] as property of the sedentary population the lands that are in the permanent and hereditary use and at the disposal of the population according to the customs of the locale, Article 262, and other articles of this statute. ${ }^{88}$

The Chaghatay version of the statute was provided to the native officials who, like the $q \bar{a} d \bar{c} s$, served the Russian administration. The translation of Article 255 seems to reflect an attempt to distinguish between rights of "use" (tașarruf) and "usufruct" (manfa'at). Be that as it may, it confirmed property rights (milk) to the local population by leaving the definition of milk to the $q \bar{a} d \bar{\imath}$ s. This explains the continuity in the way $q \bar{a} d \bar{c} \bar{s}$ notarized landed-property rights before and after the Russian conquest. ${ }^{89}$

What were Muslims' perceptions of the statutory laws on landholding? Soviet historians explained the attempt of the colonial government to produce a legislative framework leading to the creation of a patrimonial

87 I have discussed these aspects in "Colonial Legislation Meets Sharīa."

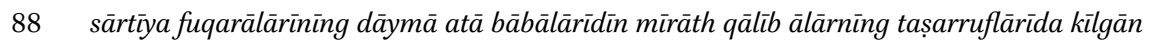
wa ālār manfa'atlānīb tūrghān mulk yirlār ūshbū jāynīng rasm wa 'ādatlārīgha wa ham ūshbū nizāmnīng min ba'd kïlādūrghān 262-nchī wa bāshqa mas'alalārīgha muwāfiq ūz mulklārī ìkānlīghïgha mustaḥkam qülīb bìrīādūr, TsGARUz, f. I-36, op. 1, d. 4008, l. 27ob. The Chaghatay translation of the statutory law was published in lithograph as Turkistān

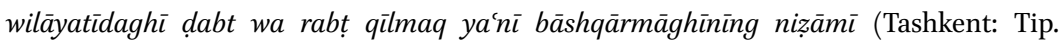
Portsevikh, 1901). Article 255 is on p. 39.

89 As shown in my "Colonial Legislation Meets Sharīa." 
state ${ }^{90}$ but this ideological claim remains unproven. ${ }^{91}$ Alexander Morrison has suggested that the Russians did away with a landed aristocracy that, before the conquest, either owned tax-exempt land (milk-i hurr) or temporary fiscal grants $(\operatorname{tarkha} n) .{ }^{92} \mathrm{He}$ has convincingly shown that former Bukharan and Khoqandi officials, such as tax collectors, lost their privileges after the consolidation of Russian rule. However, we know of no substantive disturbances caused by dispossessed landowners, a concern that, significantly, preoccupied the Ministry of War during the review of the proposal of the Ignat'ev commission, which included an article stating that the Russian government would not confirm the fiscal privileges originating from milk-i hurr. At the request of Governor-General Kaufman, the article was expunged from the statute. ${ }^{93}$ Considering that, in several districts of Samarqand Province, milk-i hurr comprised the majority of the area under agriculture, ${ }^{94}$ it is unlikely that this class of land aristocracy would have accepted the large-scale appropriation of its holdings without making a fuss. Indeed, members of this class seem to have moved with alacrity to defend their interests whenever these came under threat:

The residents of Panjshanba to the governor. We poor and miserable people appeal to you in hope of your mercy. In the wake of the conquest of Katta Kurgan, our notables went to the city in order to subject themselves to our White Tsar. [At that time], you promised us that our mulk will remain mulk and so will [our] waqfs. Now our mulks have been turned into amläk, and for this reason we poor and miserable people are deprived of our tranquility. In the hope that you will redirect this request to the governor. ${ }^{95}$

In this appeal written in Chaghatay, the notables of Katta Kurgan explained that colonial officials had reassured them that fiscal privileges on milk-i hurr

$90 \quad$ S.I. Il'iasov, Zemel'nye otnosheniiv Kirgizii v kontse XIX-nachale XX vv. (Frunze: Izdatel'stvo Akademii Nauk Kirgizskoi ssR, 1963): 80.

91 Sartori, "Colonial Legislation Meets Sharía"; Penati, "Notes on the Birth of Russian Turkestan's Fiscal System: A View from the Fergana Oblast' "; Pravilova, "The Property of the Empire."

92 Morrison, "Amlākdārs, Khwäjas and Mulk Land in the Zarafshan Valley after the Russian Conquest": 23-64.

93 Savistkii, Pozemel'nyi vopros $v$ Turkestane: 190.

94 Copy of a list of milk land drafted by a former Bukharan official under Emir Muzaffar, at the request of the Orientalist Aleksander Kuhn, 1870, TsGARUz, R-2678, f. 1, d. 381, 1-3. TsGARUz, f. I-1, op. 14, d. 28, l. unnumbered. 
and charitable endowments would be left untouched under Russian rule. The speakers seem to have understood amlāk as land from which taxes are levied; certainly, it is that way that the translator, a certain Ibragimov, glosses the word in Russian (zemlia s koei postupaet podat'v kaznu). ${ }^{96}$

There is little doubt that Russian statutory laws were, in principle, less advantageous for those who possessed milk-i hurr land. Some people also imagined that the implementation of Article 255 would create a situation in which former proprietors of estates subject to taxation (milkdār) would be demoted to tenants on a par with those who had worked on mamlaka land under the ruler of the emir and the khans. ${ }^{97}$ Regarding these specific points, a certain Mullā Kamāl al-Dīn, the first Samarqandi jurist to become a native judge under Russians rule, ${ }^{98}$ recounts a revealing anecdote. In an account of his attempt to regain the office of native judge from which he had been removed, Mullā Kamāl al-Dīn reports several conversations he had with colonial officials. In one such conversation with a certain Lieutenant Savinkov, he was asked to illustrate the existing landholding situation in Turkestan. This is Mullā Kamāl al-Dīn's answer:

The landowners [mulkdār] have been suffering severely [in recent years]." Later they [Savinkov] asked: "Is there any way to resolve this problem by taking into account the types of land?" I said: "Mulk land is of three types: one is mulk-i hurr, another is mulk-i 'ushri, and another is mulk-i kharäji. The meaning of mulk-i hurr is such that the person who tills the land does not pay anything to the treasury [khazina], whereas he pays the kharäj on the proceeds to the landowner. Mulk-i 'ushri means that, from the proceeds of the land, one-tenth goes to the treasury and two-tenths to the landowner. The meaning of mulk-i kharāji is this: from the proceeds of the land two-tenths go to the treasury and onetenth to the landowner. This makes three-tenths. Now they pay one-fifth of the proceeds from their ownership to the treasury. The rest of the proceeds go to the peasants who can take it for themselves. This law [nizāam]

$96 \quad$ Ibid.: 1.8 .

97 Rostislavov, Ocherk vidov zemel'noi sobstvennosti: 7.

98 Mullā Kamāl al-Din compiled this text after his dismissal from the office of native judge in 1871. On him, see Morrison, Russian Rule in Samarkand, 1868-1910: A Comparison with British India: $254-55$. 
has become [a source of] serious suffering for landowners, because they had invested a great deal of money to acquire this mulk land. ${ }^{99}$

At first sight, this account suggests that landowners had no means of preserving their fiscal privileges, while peasants were able to enjoy a larger share of the produce-but matters are not so simple. First, Mullā Kamāl al-Dīn points out correctly that, under colonial rule, owners of milk-i hurr land would pay one-fifth to the government. They therefore lost the absolute fiscal exemption they had enjoyed under the Bukharan emir and were lowered to the status of those who, before the conquest, owned milk-i kharājī. However, Mullā Kamāl al-Dīn's account wrongly assumes that peasants would not hand over to their landowners the rent required by their contractual obligations of tenancy. This reflects the assumption that landowners had no means of enforcing contracts. We have already seen that landowners did not hesitate to take their affairs to the colonial administration, and there is no reason to imagine that Russians would deliberately side with the peasants in every case. The bureaucratization of land tenure put greater emphasis on the importance of documents. Thus, any written attestation of tenancy obligations would ensure that landowners received what was due to them. Local landowners may well have had to pay something to the Russian government, but it would be misleading to assume that the Muslim landed aristocracy, as a class, was eradicated - in fact, the opposite was true. Notwithstanding the less favorable conditions for owners of milk-i hurr, the qā rules introduced by the Russians, to amass a fortune in landed estates in Qizil Qurghān, outside Tashkent. These lands were rented out to tenants. ${ }^{100}$

Second, one should not underestimate the key role played by native judges in helping to preserve, where possible, preconquest forms of land tenure. In notarizing transactions, native judges were bound to specify exactly what people owned, whether improvements or the soil itself. In this way, they disambiguated land-ownership from mere possession, that is, the condition of a tenant. The same applies to temporary fiscal exemptions for, say, the descendants of saints. Private collections show how such groups used documentation in the

Risāla-yi Mullā Kamāl al-Dīn, Ms St. Petersburg, IVRAN, S-169o: fols. 49a-49b. The manuscript is described in L.V. Dmitrieva and S.N. Muratov, Opisanie tiurkskikh rukopisei instituta vostokovedeniia II (Moscow: Nauka, 1975): 117, no. 70.

100 Gh. Karimov, P. Sartori, and Sh. Ziyodov, Sebzor dahasi qozisi faoliiatiga oid khujjatlar (Tashkent: O'zbekiston, 2009): doc. 117-23. 
vernacular to ensure the preservation of their privileges. ${ }^{101}$ This implied that such groups had instruments for enforcing the stipulations of deeds beyond the obvious recourse to the Russian administration. This scenario excluded the situation in which peasants could expropriate landowners.

Third, and more significantly, the bureaucratization of land tenure triggered a fierce competition to acquire land that had, before the conquest, belonged either to the treasuries of local potentates or to the crown. Muslim groups attempted to acquire such land by leveraging on the colonial bureaucratic regime that conferred higher probative force on legal deeds. If peasants had been better off than landowners, there would have been no such attempts to expand landed property. It is to this phenomenon that we now turn.

It is unclear what was the fate of the land that belonged previously to the Muslims rulers (khans, emirs) or was considered state land (mamlaka) and as such counted as property belonging to the treasury (bayt al-māl) of the khanates.

When the Russians conquered Central Asia, much of the land belonging to the Khoqand khanate and the Bukharan emirate was occupied by the local population who cultivated it and enjoyed usufructuary rights. Locals were not just tenants. The populace could and did acquire the right to install themselves permanently (haqq al-qarār) on state land by purchasing the improvements, which included plantations and buildings. This situation generated entitlements that were often subsequently formalized as quasi-property rights, but both individuals and communities acquired property rights exclusively on improvements, thereby leaving to the state the ownership of the bare substance (raqaba) of the land.

One is tempted to assume that, as the local rulers lost their powers, the population tilling state lands found themselves in a favorable position to attempt to persuade the Russians that they were the owners of the land they tilled, but matters were complicated. As the Russians established their rule in the country, they introduced a bureaucratic regime that conferred definitive probative value on deeds.

101 T. Welsford, "Fathers and Sons: Re-Readings in a Samarqandi Private Archive." In Explorations in the Social History of Modern Central Asia (19th-2oth Century), ed. P. Sartori (Leiden: Brill, 2013): 299-323. 
Under Kaufman, the first governor-general, various commissions were created to inquire into the land rights and fiscal status of the native population. We know that these commissions faced severe problems in assessing the information they gathered from the natives, and it is not clear how land-ownership was actually verified on the basis of vernacular documents. ${ }^{102} \mathrm{~A}$ project of land-assessment reorganization (pozemel'no-podatnoe ustroistvo) became one of the ambitious undertakings of the Russian administration already under the first governor-general. Government agencies (organizatsionnye raboty) were set up to prepare land assessments. ${ }^{103}$ They began in Tashkent Province (uezd) and moved on to Samarqand and Ferghana. These agencies were instrumental in establishing cadastral offices, which could provide detailed information on, for example, who tilled the land, the crop sown, and a calculation of the tax to be levied from the fiscal units. In case of the data yielded by these agencies, Penati claims that, at least in Ferghana, the land that had belonged to the members of khan's family was registered as belonging to the treasury (kazennaia). ${ }^{104}$

In other provinces of Russian Turkestan, by contrast, the fate of the land of the Bukharan emirate and the Khoqand khanate seems to have been far more complicated than in Ferghana. It appears, for example, that, in Samarqand Province, sharía courts continued to observe the distinction between private land-ownership (mulk) and state land (mamlaka) that had existed before the Russian conquest, under the rule of the Bukharan emir. They did so by notarizing zealously all transactions of property rights pertaining to improvements of state land. ${ }^{105}$ In most cases, these transactions involved buildings and plantations on land of agricultural significance. Had the Russian state converted land formerly belonging to the emirate (mamlaka) into treasury land (kazennaia), the individuals who acquired property rights on the improvements of such land (as sanctioned by sharîa courts) would have been lessees of the Russian government. Lacking any other evidence, it is difficult to say what kind of certification of lease the Russian administration could issue in favor of these individuals. These people were installed on land of agricultural significance, that

102 Penati, "Notes on the Birth of Russian Turkestan's Fiscal System: A View from the Fergana Oblast'”: 744 .

103 Land assessments, however, were made on the basis of cadastral surveys that had no legal force. See TsGARUz, f. I-17, op. 1, d. 30291/23.

104 Penati, “Notes on the Birth of Russian Turkestan's Fiscal System: A View from the Fergana Oblast' ": 759 .

105 Welsford and Tashev, A Catalogue of Arabic-Script Documents from the Samarqand Museum: doc. 131, 461a, 463, 464, 465, 467, 468, 470, 498, 501, 515, 525, 534, 547, 568, 598, $599,600,616$. 
is, in rural settlements. Had these rural areas been surveyed by the land-assessment agencies, the people in question would probably have come to belong to a rural community (sel'skoe obshchestvo).

The rural community was a fiscal entity that was copied from the Russian "commune" (mir). Rural communities were responsible for the apportionment (raskladka) of the land tax, which was calculated "on a sampling of local yields, multiplied by the average market price of that produce for the five previous years." 106 While land assessments were in the hands of the Russian militarycivil administration, decisions on who paid what were made by the headmen of the rural communities. The sel'skoe obshchestvo was a colonial creation that had no counterpart in local parlance or in that of the native courts. Members of such communities thus continued to secure their rights to land through notarization in the native courts. ${ }^{107}$ Individuals exchanged plots of land not only within rural communities but also across community boundaries, but deeds issued by native judges were insufficient to sanction land-ownership in the rural communities. The amendments of 1900 to the statute allowed individuals to leave rural communities. The procedure that led to the assignment of a plot of land in a rural community was called $v y d e l$ ' and consisted of acquiring a certificate of possession (vladenie). This certificate was called a dannaia. ${ }^{108}$ There is no apparent connection, however, between the legal deeds that members of the rural communities acquired from native courts and the dannye that they received from the colonial administration. The overlapping rights reflected in these two different genres of bureaucratic text created a chaotic situation. It required only knowledge and expediency for the locals to take advantage of this situation to pursue their own goals.

While there were $q \bar{a} d \bar{i}$ s who, under Russian rule, acted as the watchdogs of the land formerly belonging to the emirate and the khanate, there were other local actors who attempted to take advantage of the blind-spots in the land surveys to take possession of state land. I hope to show that local groups had an

106 B. Penati, "The Cotton Boom and the Land Tax in Russian Turkestan (188os-1915)." Kritika 14/4 (2013): 747 .

107 Native judges notarized sales of plots of land within rural communities by omitting the plots' cadastral numbers. This is reflected in a collection of deeds pertaining to plots of land in Mahram County, in the district of Khoqand, where transactions took place in 1909. See Kollektsiiai fondi shaxsii Mullomuhammad Sharif ibni Abduzalil [sic!-Mullā Muhammad 'Aż̀m Mullā Muhammad Sharîf-ūghlī]: qozii volosti Mahram, ObAKh, f. I-145, op. 1, d. 58 , ll. 1-20.

108 On the vydel, see Sartori, "Colonial Legislation" and B. Penati, "Beyond Technicalities: On Land Assessment and Land-Tax in Russian Turkestan." JFGO 59/1 (2011): 1-27. 
interest in the nonirrigated ("marginal") lands such as pastures (yaylāw) and regarded it an advantage to turn it into private property.109

\subsection{Case Study: Partners in Profit}

Let us turn now to a revealing legal dispute over land belonging to the treasury of the former Bukharan emirate. The case pertains to competing claims to an area of one hundred țanābs of rain-watered land (zamin-i lalmí-kār) that had, before the Russian conquest, belonged to the Bukharan emirate. The contested land was situated in Kalta-Sāy, in the lower valley of the Shīrāz district (tümān), in the region of Samarqand. Although its origins can be traced back to the mid-185os, the dispute intensified only after the Russian conquest, when the territory in question came under colonial administration.

The earliest evidence available indicates that in March-April 1856, in the sharīa court of the Shīrāz district, the Tuyāqlì Mullā-Kīk community (jamā'a) acknowledged the receipt of a spring in a place called Lây Chashma, in the aforementioned locality, for the irrigation of $5^{0}$ qus $h^{110}$ of land. They also declared that they had dug the spring, canalized its water, and irrigated the surrounding land according to their established practices (ba-qadr-i rasm-i khwudhā). The representatives of the Tuyāqlī Mullā-Kìk community also acknowledged before the $q \bar{a} d \bar{l}$ an agreement that they had reached with their fellow kinsmen from the Tuyāqli Jangal community. This consisted of the transfer (taslìm) of possession of a spring in Ūzūn-Sāy, in the aforementioned lower valley, for the irrigation of 20 qūsh of land. The transfer had been made so that the Tuyāqli Jangal community could dig the spring in Ūzūn Sāy, irrigate the land with its water, and develop certain forms of agriculture (gasht wa zarāact). Apparently, two Tuyāqlī communities divided among themselves the state land in KaltaSāy, by allotting the rights to two neighboring springs, one in Lāy Chashma, the other in Üzūn-Sāy. The Islamic legal record makes clear that the two parties did

109 As marginal lands, pastures received special fiscal treatment by the Russians. According to the 1886 statutory law, taxes on rain-watered land were levied at the rate of $10 \%$ of the actual yield of the harvest; after the amendments brought of 190o, taxes were instead calculated in proportion to area. It is unclear whether this change in fiscal policy was instrumental in instigating native attempts to seize marginal lands; the evidence so far collected does not give a consistent picture.

110 Qush is the Chaghatay rendering of the term juft. It signifies the amount of land that can be tilled using a single pair of oxen (juft-igāv). See Semenov, Ocherk pozemel'nogo-podatnogo ustroistva b. Bukharskogo khanstva: 53 . On the qush as a variable variable measure of land area, see E. Davidovich, Materialy po metrologii srednevekovoi Srednei Azii (Moscow: Nauka, 1970): 122-23. 
not own the land there but that they had only received the springs and their water to use in cultivating the surrounding land.111

This was the situation when the Russians came to Central Asia. The situation evidently deteriorated in 1897, when three members of the Tuyāqlī MullāKīk community—Bigīm Qul Mīrzā Bāy, Qul Bigīm, and Ḥasan Naẓar—sold 68 tanābs of the rain-watered land in the locality of Ūzūn Sayy to several people belonging to the Turk community. ${ }^{12}$ As Ūzūn Sāy was known to have belonged to the Bukharan state, the native court certified not the sale of the land itself but only of its improvements, that is, the cultivated land. In other words, this legal record shows that Bikīm Qul Mīrzā Bāy, Qul Bigīm, and Ḥasan Naẓar sold only their usufructuary rights to the land. Nearly one month after the issuance of the shari $a$ court record, ${ }^{113}$ however, the three vendors persuaded the headman (volostnoi upravitel') of Tuya-Tartar County and a local notable (āqsaqāl) to aver that the 68 tanābs of land mentioned in the legal record were their own property $(m u l k) .114$

At the end of 1897, twenty-two residents of the Inichka settlement (qishlāq), in Chashma-Āb County of Jizzakh Province, petitioned the military governor of the Samarqand region. The residents were all members of the Tuyāqli Jangal community who claimed that, from time immemorial, they had had the use of about 400 țanābs of rain-watered land (bahārī-kärlīk), which they had inherited from their forefathers (qadìm al-ayyāmdān àta-bābālārmizdān). They did so by referring to a legal certificate in their possession, which attested to their rights. They also explained to the Russian authorities how they used the land. They said that every year, in spring, they cultivated it and lived off its produce. Problems began when Bigìm Qul and Qul Bigīm, who were residents of Bīdāna, sold about 100 tanābs to the Turk community, residents of UsmatQatartar County. The sale was apparently solemnized by the native court in Shīrāz, which issued a legal certificate. ${ }^{115}$ The residents of Inichka asked the Russian authorities in Samarqand to come to their assistance and help them ascertain the truth about the case.

Lieutenant Kolchanov, head of the suburban area (prigorodnyi uchastok) of Samarqand Province, was put in charge of the preliminary investigation of the case. He checked the native court records that the claimants mentioned

\footnotetext{
111 TsGARUz, f. I-21, op. 1, d. 475, l. 5 .

112 30.06.1897, ibid.: 1. 6.

113 27.07.1897, ibid.: l. 6ob.

114 üshbū wathīqa ichīda yāzīlgān 68 țanāb yir wajhìdān taftīsh qüldūm ūshbūnì ichīda maḍūr Bigìm Qul [...] haqq wa mulkī ı̄kān, ibid.

115 Ibid.: l. 9 .
} 
in their petition and found that the "indigenous document" (tuzemnyi dokument) proved that "the land in the localities of Lāy Chashma and Ūzūn-Sāy (20 qüsh of land) was allocated to a community [priznan za obshestvom] of the Tuyaqli clan $[\mathrm{rod}]$. To this latter clan belonged both the parties to the dispute." Kolchanov added that the 20 qush appeared to belong partly to the residents of Inichka and partly to the residents of another settlement, called Bīdāna. It seemed to the Russian official that the residents of the latter settlement had sold their shares of rain-watered land long ago and that they tried to appropriate the shares belonging to the Inichka residents. They did so by selling secretly nearly 100 țanābs to the Turk community.

Kolchanov seems to have received little help from his translators. His report shows that he misunderstood much of the content of the shari'a court record provided by the Inichka residents. Kolchanov held that the land in Üzūn Sāy was "shared" by the residents of Inichka and Bīdāna. In fact, the record indicates that people from Inichka had rights to the land in Ūzun Sāy, whereas the other party—the Bīdāna residents, members of the Tuyāqlī Mullā-Kìk community - had usufructuary rights to Lāy Chashma. Kolchanov's faulty knowledge of the vernacular languages also prevented him from reconstructing properly the sequence of the documents and thus grasping the stratagem concocted by Bigim Qul and Qul Bigim, together with the county headman and the $\bar{a} q s a q \bar{a} l$, to sell state land as if it were their private property. When Kolchanov questioned the qā $d \bar{\imath}$ who had notarized the sale deed, the latter answered that he had agreed to issue the deed because the county headman and the $\bar{a} q s a q \bar{a} l$ had confirmed that the land belonged to the sellers. Apparently, Kolchanov could make no sense of the documents in Persian and in Chaghatay and thus overlooked a major discrepancy between them: in the native court record, the object of the transaction was the improvements on rain-watered land, whereas the affirmations produced by the county headman and the head of the rural community showed that the object of sale was private land. ${ }^{116}$

The end of this story reveals that Russians could not always prevent the indigenous population from seizing what was, before the conquest, state land. The Russian authorities ruled that the dispute should be adjudicated by an extraordinary assembly of $q \bar{q} d \bar{l} \bar{s}$. The latter gave a concise report of the hearing, stating that, when the claim of the agent of Inichka residents for the usurped land was denied, the $q \bar{a} d \bar{c} \bar{s}$ asked the plaintiffs to produce testimony of their claim. Interestingly, it seems that they did not review the sharita court record, which had been issued in the precolonial period. Instead, as the plaintiff could not provide the requested probative evidence, the judges asked the defendants

116 Ibid.: 1l. 4-4ob. 
to swear an oath. At this point, a third party intervened and suggested settling the dispute amicably, and the defendants paid 1,500 tangas for the land in question. ${ }^{117}$ As we shall see, settlements would be a successful instrument in the hands of the locals in securing land-ownership rights to estates they attempted to seize.

\subsection{Case Study: Troubles in Jalayir}

On 5 January 1887, I reached Qara Quduq early in the morning, together with 'Abd al-Sattār, who had formerly served as qaḍi, and Mullā Birdī Bāy, a qaḍ̄ [presently on duty]. The head of Zaamin County, Mullā Darwīsh, and forty notables [pochetnye] [also were with me]. [I was also followed by] Balabanov, a translator, and two guards [jigits] in the service of the provincial chancellery. As soon as we reached the place, [a crowd of] nearly a hundred individuals gathered [before us]. They were Uzbeks belonging to the Turk and Jalayir clans [rod]. We found there barns for the cattle and cultivated fields. The qä $\bar{d} \bar{i}$ and others told me that [the premises] were built last year. While facing the crowd, I read aloud the decision of the Muslim judicial assembly and your order [instructing that those improvements be torn down]. As soon as I finished [reading it], Mullā Rustam yelled at me that, as long as he lives, nobody would ever touch those buildings. After that, he took out a knife and threw it before my feet. He then laid his head on the ground and began to shout at me, asking that I chop off his head with that knife. When the headmen of Zaamin County climbed on the roof of one building in order to execute [the removal of the buildings], the Faydullāh brothers, their relatives, and even their wives took measures to counter my orders. They tried to spread chaos and to get the county headmen down from the roof. The crowd [was all around and] pushed me. I could not move. The two guards heard that somebody was calling on the people to pull out their knives in order to defend Mullā Rustam. In the end, [I was able to] arrest him and his brothers. I immediately dispatched them to Jizzakh, awaiting your command. During many years of service, I have never experienced anything resembling this event, and I felt anxious and frightened [ $\mathrm{vzvol}$ novan i potresen]. As I was leaving, the Jalayirs began to beat up the Turks.

117 13.01.1899, copy of the decision, ibid.: l. 38. 
I cannot say who beat whom, because everybody was fighting. The Turk people mounted their horses and rode away. ${ }^{18}$

This was the end of the story of one family trying to get hold of state land in a mountainous area of Jizzakh Province, which had, before the Russian conquest, belonged to the Bukharan emirate. The story is not one of heroic resistance by subaltern subjects against domination by Russians in Central Asia. Rather, it is the last act of a drama that centered on local communities who were asserting emotionally their aspirations concerning land rights, of which they had no proof.

The story can be traced back more than twenty years. For at least a generation, two communities (jamácat), the Jalayir and the Turk, had been involved in a competition over water and land resources along a stream called Jalayir. The stream runs from south to north, nearly 20 kilometers east of Zaamin, in a poorly irrigated area. There was a rural settlement (mawda /qishlāq) and a summer pasture (yaylāw), both named after the stream. The confrontation between the Jalayir and the Turk led to blows, when one community usurped the summer pasture attached to the settlement, cultivating it for themselves and refusing others access to it. At this point, the story becomes more complicated, as a third community asserted rights to the pasture. But let us start from the beginning.

The earliest evidence available in the records collected by the Russians on this case is a document from May 1861. At this time, a few years before the Russian conquest, twenty-four people appeared before a $q \bar{a} d \bar{l} \bar{\imath}$ in Ura-Tepe, which was, at that time, a small semi-autonomous principality, highly unstable politically, ${ }^{119}$ seemingly under the formal control of the Bukharan emirate. These individuals intended to register a substantial change in the way they had been sharing the water of the Jalayir stream. Until that time, the water had been accessible and was distributed on the basis of a sequence of twenty daily shares according to an old custom of the local populace (mushtamal bar dawrayi bìst shabāna rūza ba rasm-i qadìm-i ahālī). The group of people owning (mālikin) the water decided to seek the notarial services of the $q \bar{a} d \bar{q}$ in Ura-Tepe in order to add another three shares to their water allotment. Accordingly, they transferred the ownership (tamlik $)$ of one share of water (yak $\bar{a} b)$ to three individuals, Rajab 'Alī Bāy, Subḥānqulī, and Sawīr Qulī Bāy. The latter handed over 14,00o tangas to the most prominent member of the group, one Mūsā

\footnotetext{
118 Report, Captain Rybushkin to the commandant of Jizzakh Province, 06.o6.1888, TsGARUz, I-21, op. 1, d. 56, l. 58 .

119 Materialy po istorii Ura-Tiube. Sbornik aktov XVII-XIX vv.: 4.
} 
Dīwānbīgī, thus extinguishing an earlier debt. ${ }^{120}$ As his title "Dīwānbīgī" suggests, Mūsā must have held a prominent administrative office as tax surveyor in the emirate. ${ }^{121}$ He must have exerted his authority and requested that his three fellow group members pay that considerable sum of money to be entitled to ownership rights to the water. A few months later, Mūsā Dīwānbīgì appeared before the same $q \bar{a} d \bar{\imath} \bar{l}$ and acknowledged that he had a duty to perform, consisting of paying to Rajab 'Alī Bāy, Savīr Qulī Bāy, and Mullā Rustam (brother of the aforementioned Subḥānqulī) exactly the same sum of money as he had received. We do not know why he had to return the money to its former owners. This course of action, however, is noteworthy because it marks the rise of a smaller group among the Jalayir community. The latter's internal balance of power shifted in favor of the offspring (awläd) of a certain Fayḍullāh. Two of his sons, Mullā Rustam and Subḥanqulī, each owned two shares of water. A few years later, the latter and their seven brothers secured ownership (mulk) of 200 manns $^{122}$ of land in the settlement of Jalayir. This portion abutted another ancestral undivided estate $(m u s h \bar{a})$ belonging to Faydullāh's sons who were thus expanding their possessions. ${ }^{123}$

Fayḍullāh's offspring, notably Mullā Rustam, did not conceal their ambition to get hold of the land belonging to the Jalayir settlement. They revealed their intentions clearly after the Russian conquest, when they seized an area in the mountainous locality of Qara Quduq. When this happened, the people from Jalayir, notably a group around a certain Ibrāhīm, complained that this land had been traditionally kept as summer pasture and that only part of it was used for small-scale agriculture. In early 1884 Mullā Rustam and other six individuals were accused by another group of having usurped the land and prevented the Jalayir residents from accessing it. Mullā Rustam's opponents brought the case to the attention of the Russians. They argued that they possessed approximately 1,00o batmans of land, inherited from their forefathers, which consisted of arable land and summer pastures (takhminan ming batmānlïkyir qadìm al-ayyāmdān āta-bābāmìzdān qülghān îkìn wayaylāw jāylārimìz ìdì). The

120 TsGARUz, I-21, op. 1, d. 56, l. [8].

121 Mīrzā Badī‘ al-Dīvān, Majma` al-Arqām (Predpisaniia Fiska). (Priemy dokumentatsii v Bukhare XVIII v.), ed. A.B. Vil'danova (Moscow: Nauka, 1981): 54, 97.

122 Mann (or man, from bätman) is usually employed as a measure of weight. Davidovich, Materialy po metrologii srednevekovoi Srednei Azii: 85-94. It was also used, as in this case, to denote the area that could be sown with a specific quantity of seeds. See Kh.A. Kaiumova, Narodnaia metrologiia i khronologiia Tadzhikov Karategina, Darvaza i Zapadnogo Pamira $X I X-$ nachala XX vv. Synopsis of PhD diss. [avtoreferat] (Khojand, 2009): 16 and 18.

123 TsGARUz, I-21, op. 1, d. 56, l. 9 ob. 
appellants informed their Russian addressee that Mullā Rustam and his affiliates were spreading the rumor that they had purchased (șâtīb āld $\bar{u} k$ dīb) the land in Qara Quduq. This piece of information, whose crucial importance we recovered only after the fact, is instrumental in situating the following course of events in the context of Russian legislation: could Mullā Rustam and his men buy that land? ${ }^{124}$ This appeal led to an inspection showing Mullā Rustam's muscular behavior with the purpose of acquiring land-ownership. This was a war waged with documents rather than with weapons. The number of documents grew, along with the fortune he was amassing.

Captain Rybushkin, assistant to the commandant of the Jizzakh raion, led the investigation. He concluded that the land had never been made arable and that it was, instead, a summer pasture belonging to the Jalayirs. If this land were to be made arable, the nomads (kochevniki) would lose their summer pastures. Both parties were forbidden to turn this land into arable land, argued Rybushkin, whereas it was perfectly lawful for the Jalayirs to use it as pasture. The Russian officials therefore ruled that the cultivation of the land in question should be forbidden to both the parties, according to resolution no. 2674 of the governor-general, dated 22 April 1882, until the land-tax assessment should be carried out; the Jalayirs should be accorded the right of using that land as summer pasture and bringing their flocks there. ${ }^{125}$

Ibrāhīm and his community were not satisfied with this decision. A few months later, they complained that the new prohibition of plowing those lands affected their finances substantially by reducing greatly the production of the land. Accordingly, he and his fellow clan members asked to be allowed to till the land that belonged to them (prinadlezhashii nam). ${ }^{126}$ This argument attracted the sympathy of Pankratov, the head of the Jizzakh raion, in whose eyes Ibrāhim seemed to be defending the interests of a group of poor against the party of the rich led by Mulla Rustam. Pankratov was convinced that the request of Ibrāhīm was just (spravedlivo) and concluded that it would be reasonable to allot to his party some of the pasture for conversion into arable land. ${ }^{127}$ Pankratov's superior, the commandant of the Khojand Province, agreed in principle with his observations but noted a glaring contradiction between Pankratov's recommendations and the information that he had gathered on

\footnotetext{
124 Ibid.: l. 1.

125 Ibid.: 1. 3-4.

126 N.d., ibid.: 1. 13. Similar petitions were submitted on 31 July 1884 and 22 August 1884, respectively, ibid.: 1.14 and $15^{-15}$ ob.

127 24.08.1884, ibid.: l. 16.
} 
the land in question:128 the land had never been tilled and had always been used by nomads ( $v$ pol'zovanii kochevnikov). "Therefore", asked the commandant of Khojand Province, "if some of [the Jalayirs] till this land, would this act not contravene [the idea that the land] is the summer pasture of these nomads? If this is not the case and the nomads have enough land for their summer pasture, then I ask you to allow the poor party to till it."129 It was natural for the Russians to assume that the people who used pastures were nomads.

As in the preceding case of Üzūn Sāy, the parties to the dispute resorted to a native court to settle their conflict amicably. Mullā Rustam, acting on behalf of forty households, acknowledged a settlement of the dispute between the people they represented and the party of Ibrāhim over the land of Qara Quduq, which consisted of fallow and pasture land (zamin-i büz-i mar'ät wayaylāw). In exchange for the release of the previous claims, a substantial portion of land in Qara Quduq became the shared property of Mullā Rustam and his brother Hasan and the community on whose behalf they acted (ba māyañn wa jamā'a-i mu'akkalīn makhșūs gardānīda). ${ }^{130}$

By filing a claim against a fellow member of a community, one could acquire rights to a pasture and notarize them as a deed of amicable settlement. With a certificate issued by a native court, which solemnized such rights, it would be easy to persuade the Russians that one's position was sound. The Jalayirs were clearly aware that the bureaucratization of property relations was instrumental to seizing pasture. Mullā Rustam had just received a copy of this document when two members of his community again petitioned the Russians:

This year, the assembly of qädīs issued a decision on the land in Qara Quduq. The $q \bar{a}$ dīs gave two copies of the decision, one to our group, that is, forty households, and one to the party of Ibrāhim, of sixty households. Now, when we suggest dividing the land between our forty households and cultivating it, Mullā Rustam claims that the [quậī's'] decision involves him alone and does not concern us. In order to avoid further conflicts, we ask you to order that our land be divided. ${ }^{131}$

An $\bar{a} q s a q \bar{a} l$ of Zaamin was immediately dispatched to make an inquest. Reporting to the authorities in Jizzakh, he explained that, as a consequence

\footnotetext{
128 Ibid.: 1. 4ob.

129 Ibid.: l. 16ob.

130 January-February 1885, ibid.: l. 20 .

131 Bīk Kīldī Muhammad Khwāja-ūghlī and Bābā Āqsaqāl Aḥmad Ṣûfī-ūghlī to Pankratov, 20.11.1885, ibid.: 1. 25ob.
} 
of the conflict over Qara Quduq, the residents of the Jalayir settlement were divided into two groups. The first comprised sixty households, the second forty. The former claimed that they intended to cultivate the land. Mullā Rustam and his forty households argued that the land should not be cultivated and should be retained as summer pasture. But Mullā Rustam lied:

As he and his men took the water from a small river nearby and plowed and cultivated an area, Mullā Rustam claimed that the land in question belongs to him [yirim haqqim]. They cultivated an area of six puds of barley [a pud could produce about $100 \mathrm{~kg}$ of barley]. They cultivate another five puds of barley in a place called Îlānlī, a pasture above Qara Quduq. Beside this, in a place even higher, he plowed land that measured about sixty puds, which [in the past] had been already tilled [āq yir]. Some of it is cultivated in wheat, some in barley, and the rest has been left fallow [qūrūq]. Above, there is also a pool [hawḍ] from which water is taken for irrigation. ${ }^{132}$

In order to strengthen his rights to the land he cultivated, Mullā Rustam claimed he had paid a land-tax and asked that the members of his group contribute to such expenses. Twenty-one households refused to do so and claimed, instead, their own share (hisssa) of the land that they would plow independently (zarā'at qülämizz). Mullā Rustam opposed them, requesting that they first pay a share of the tax to till the land in Qara Quduq. "Should they not be able to pay," concluded Mullā Rustam, "the twenty-one households would continue to use the land as summer pasture."

The Zaamin $\bar{a} q s a q \bar{a} l$ was the first to understand that, if knowledge of this case were to spread, other groups might attempt to seize pastures for agricultural purposes. Indeed, he informed the Russians that there was also another community, the Turks, who had rights to the pastures of Qara Quduq, which amounted to two months in the summer of every year. He also warned the military-civil administration that, if taxes were collected from the party of the twenty-one households and the latter were allowed to cultivate the land, the Turks might advance the same claims. The $\bar{a} q s a q \bar{a} l$ was clearly recommending that the Russians preserve the land in Qara Quduq as summer pasture to avoid conflicts and social disturbances. ${ }^{133}$

$132 \quad 05.12 .1885$, ibid.: 1. 310b.

133 To the head of the Jizzakh uezd, 24.11.1885, ibid.: l. 24. 
A day before the Zaamin āqsaqual sent his report to the head of the Jizzakh district, the Turk community made a strategic move by appealing to the Russians:

Even though the assembly of $q \bar{a}$ dīs ruled that our land should remain summer pasture and communal property, Mullā Rustam and his community has tilled it and cultivated it, even though the two parties had reached an agreement, according to sharîa, that the land should remain pasture. Now we too want to cultivate our land and therefore appeal to you to order a trustworthy person to deal with the case in order to avoid future conflicts. We ask that our right to the land be upheld and that we be allowed to use it as we see fit, whether we want it as summer pasture or as cultivated land. ${ }^{134}$

The Zaamin $\bar{a} q s a q \bar{a} l$ was dispatched again to Qara Quduq and found that it was established practice that the Turk community would every year open a well at Qara Quduq for their cattle. That year, however, Mullā Rustam with his men prevented them from doing so. The Russians decided to arrest Mullā Rustam for seven days on a charge of seizing land illegally and asked the $\bar{a} q s a q \bar{a} l$ to take measures to prevent other landholders from restricting the access of other, less wealthy, individuals to the pasture. ${ }^{135}$

In the meantime, justice was served. A native court of six $q \bar{a} d \bar{l}$ s ruled on the dispute between the party of Mullā Rustam, his brothers, and other residents of the Jalayir settlement and the Turk community. The qādis compared with their court register a copy of the decision, which they had issued and entrusted to the Turks. The year before, they had found that Mullā Rustam and his brother had admitted that, from ancient times, the Turks had been using the land in Qara Quduq as a summer pasture and its water and that the two had never prevented the Turks from doing so. The Turks too had acknowledged that, if Mullā Rustam and his people would agree not to prevent them from accessing the land, they would drop their claim. The conflict thus ended in an amicable settlement, ${ }^{136}$ but Mullā Rustam took a new tack, requesting that the land in Qara Qudud be registered as the property (milkiyat) of his community, even though his property rights were not evident. The qā

134 Raḥmān Bāy Karīm-ūghlī, Mullā Īgam Birdī Ḥasan-ūghlī, and 'Alī Murād 'Awaḍ-ūghlī acting on behalf of 170 households of the Turk community (jamā'a), 23.11.1885, ibid.: 1. 26 .

135 See the Russian's decision in the right margin of ibid.: 1. $310 b$.

${ }_{13} 6$ ūshbū țarīqada ibrä’ wa musālaḥa būyincha sāf bülghān, 15.03.1887, ibid.: 1. 36. 
explained that four certificates of release (türt khatț-i wathiqqa-yi ibrä), which he had ready, did not prove that he could use the land as his own property (mulk bülmāydür). In fact, Qara Quduq was, the legists explained, state land (pādshāhlïk mamlaka), and the two parties should use it, provided that they used it as a pasture (īkkāwi ham yaylāw qülīb mutașarrif būlmāqlārì darkār) [Fig. 12]. ${ }^{137}$

After the decision of the native court, the provincial chancellery issued a regulation requiring the local headmen (illīkbāshì) to accompany any group (qaysi jamāadan būlsa) that applied before a native court for the notarization of a transaction in land. In their absence, the $q \bar{a}$ ḍis should not issue documents. The Russians evidently understood that there was a danger that local power holders might expropriate land formerly belonging to the state. ${ }^{138}$ They were right: Mullā Rustam appealed in the meantime to another native court, requesting the issuance of documents regarding a large area of land. Even though the native judges were unwilling to support him-this itself is evidence that not all $q \bar{a}$ ḍis were easily corrupted-Mullā Rustam did not give up on his plans. Two years later, information reached Jizzakh about a man using Qara Quduq for agricultural purposes ${ }^{139}$ who had furthermore built some barns there. ${ }^{140}$ Skirmishes between the party of Mullā Rustam and the Turk continued until the commandant of the Jizzakh raion ordered that the former be exiled. ${ }^{141}$ The Russian official noted that Mulla Rustam was a man particularly harmful to the prestige of Russian rule in the region. He depicted Mullā Rustam as a local rich man (bogatyi mestryi kulak) who failed to obey the Russian authorities. The commandant argued that, if stern measures were not taken to punish his riotous behavior, he might come to enjoy great popularity among the local population. ${ }^{142}$

While Mullā Rustam was attempting to seize the land in Qara Quduq, fighting Ibrāhīm and holding the Turk community at bay, he and other Jalayirs had opened another front in the conflict for irrigated land (zaminn-i ābi-kārî) against the Balghalis, a neighboring community. The area in question was situated around a settlement called Shahid Kutchi, on the Aq-Bulaq stream,

\footnotetext{
137 Ibid.

138 Headmen of the Jalāyir settlement to the head of the Jizzakh uezd, n.d., ibid.: 1. 20.

139 Mullā Darwīsh reported about the fact that the buildings were not removed and that the people had been cultivating the land four months later, cf. ibid.: 1. 40.

140 Commandant of the Jizzakh uezd to his adjutant, Rybushkin, 19.09.1887, ibid.: ll. $41-420 b$.

141 15.01.1888, ibid.: 1. 68.

142 Commandant of the Jizzakh uezd to military governor of Samarqand Province, 10.10.1888, ibid.: 1.78 .
} 


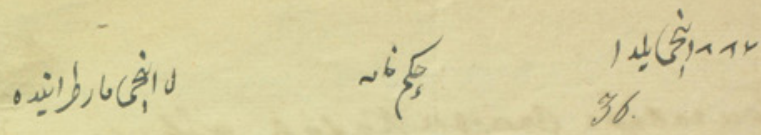

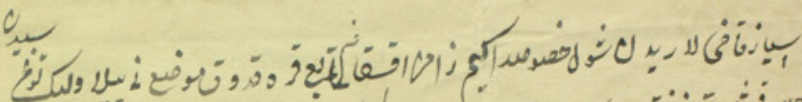

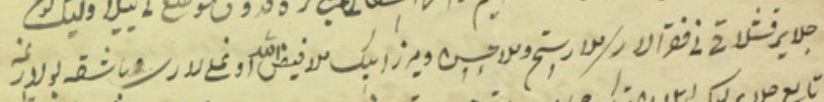

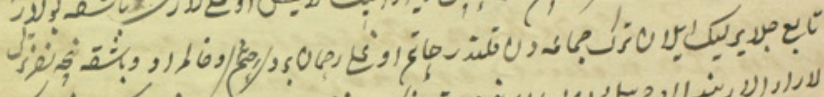

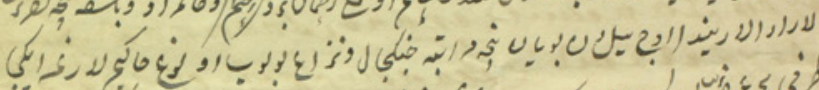

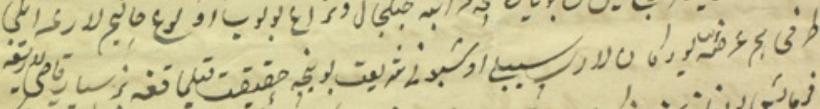

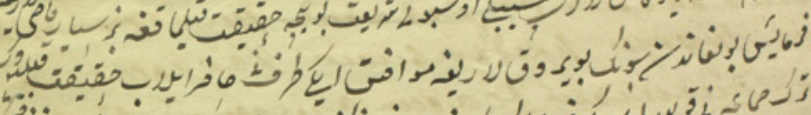

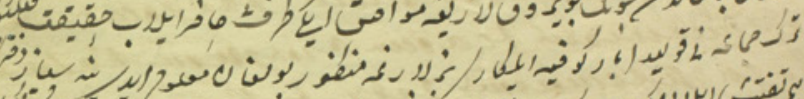

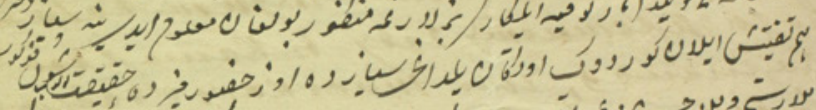
أد 3.

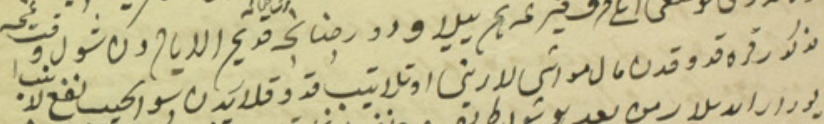

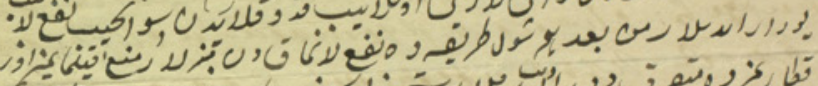

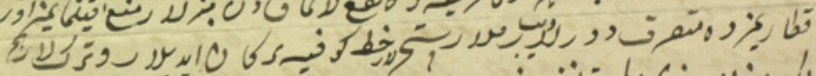

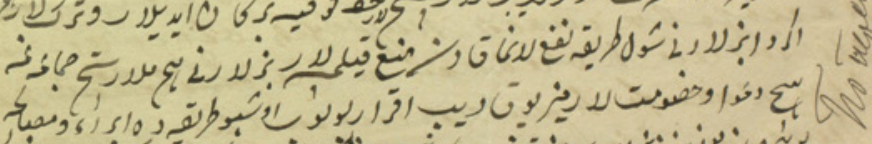

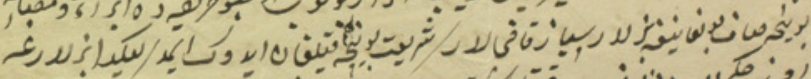

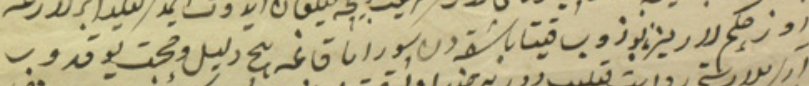

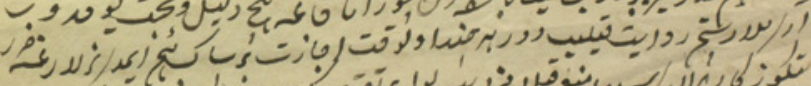

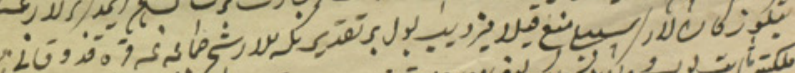

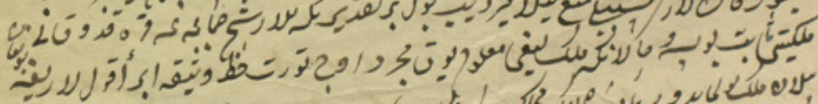

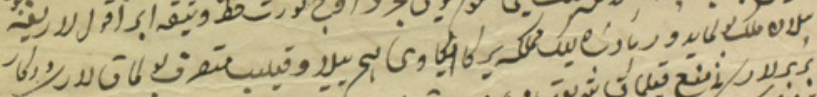
:

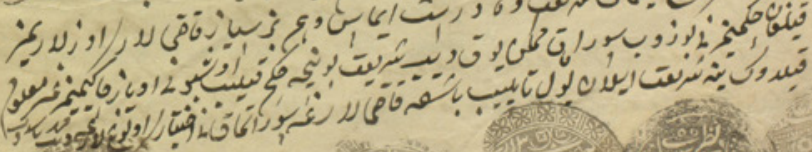
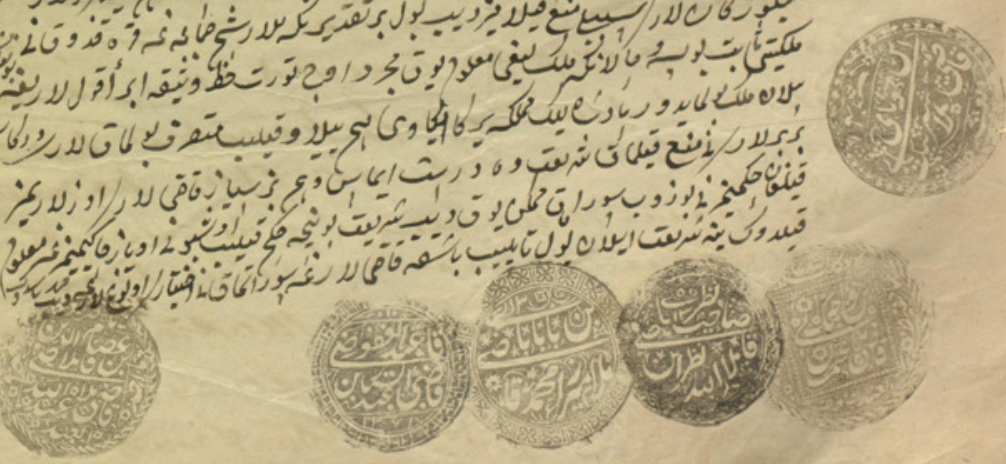

FIGURE 12 Record of a ruling issued by the native judicial assembly of Zaamin, 15.03.1887, TsGARUz, I-21, op. 1, d. 56, l. 36 .

COURTESY OF THE CENTRAL STATE ARCHIVE OF UZBEKISTAN 
a few kilometers east of the Jalayir settlement. The situation was particularly disadvantageous for the Balghalis, because the land was surrounded by areas of ancestral undivided property (mush $\vec{a})$ in the possession of other communities. One such community was the Jalayirs. The first round of conflict ended in 1881, when representatives of the Balghalis and the Jalayirs met at a native court in Zaamin. The parties concluded a settlement according to which half of the contested area and the corresponding water shares of the Aq-Bulaq would be counted as property (haqq wa milk-i khäliṣ) of Mullā Rustam and Ibrahīm and the groups of Jalayirs whom they represented. ${ }^{143}$

The conflict between the Jalayirs and the Balghalis resumed in 1904, when the land-tax commission assessed the situation. As the two communities could not agree on the boundaries of the area, the commissar of the Jizzakh land-tax commission requested the involvement of the police chief (pristav) of the Zaamin raion. This is how the Russian official recounted the scene that unfolded as he reached the locale of Shahid Kutchi:

On the spot, I found that the Jalayirs claimed that their land abuts the land of the Balghali settlement. So it does, on the western side, along a road. However, the residents of the Balghali qishlā $q$ contested this border and located it $1 \frac{1}{2}$ versts further west on rain-watered land. I inspected the available documentation. [...] On the basis of these deeds, I could not determine the western border. I decided to pass the case on to the native court. In my presence, two attorneys representing each side were chosen. They agreed that the case should be transferred to the competence of an assembly of judges to whom I explained the issue in detail. I ordered them to determine precisely the western border and leave untouched the cultivated lands, because the latter had already been divided by a native court in 188 . The native judicial assembly came to the spot and issued a decision based on an oath. This decision identifies the western border with the road heading to the qishlāq. In this way, it includes part of the settlement and cultivated lands. [...] This is not in accordance with the previous ruling. In addition, the Jalayirs received part of the settlement, which includes buildings, a mosque, and an old graveyard, together with rain-watered and pasture land and nearly all the water. [...] Given the fact that the native judicial assembly did not determine the western border and notwithstanding the order not to touch the cultivated land, I, together with the residents of the two qishläqs, the commissar, and a land assessor [zemlemer], walked to the western side

143 Certificate of acknowledgment, five $q \bar{a}$ ḍis's stamps, 24.05.1881, TsGARUz, f. I-21, op. 1, d. 634, l. 27. In Persian; abridged version in Chaghatay, ibid.: 1. 21. 
from the Balghali qishlāq, to the Aq-Bulaq spring, and began to determine who cultivates what. In this way I wanted to determine the de facto possession [fakticheskoe vladenie]. The two parties began to produce evidence and indicate precisely where the cultivated lands are located. It turned out that the pasture land is used by both parties. According to the evidence on the de facto possession [po viiasneniiu fakticheskogo vladeniia], all the cultivated land and the entire qishlā $q$ should be considered as belonging to the Balghalis, [whereas] part of the rain-watered land and about one-half of the pasture should be considered as belonging to the Jalayirs. I, together with Captain Rubakhin and the assessor Pleger, drew a map [glazomernyi chertezh] on which we laid out a proposal for a redefined border between the Balghalis and Jalayirs. The Balghalis agree, but the Jalayirs insist on their evidence and express dissatisfaction with the project, as they wished the border to be identified with the road. ${ }^{144}$

The Balghalis thus appealed against the decision of the $q \bar{a} d \bar{l} \bar{s}$. The case was reviewed by the okrug military court in Samarqand, which collected the depositions of several people. Among them was the land-tax commissioner Captain Rubakhin, who provided a revealing insider's account of the conflict. He said that the dispute was initiated by a few immoral (nedobrosovestnye) residents of Jalayir, who were led by 'Alī Bīk (son of Mullā Rustam), a former county headman who had been imprisoned for bribery (za podkup). Rubakhin noted that the only thing that 'Alì Bīk had in support of his claims was the nativecourt record issued in 1881, which gave a terse description of the division of land between the Jalayirs and Balghalis. The commissioner also noted that the Jalayirs exploited the absence of more ample documentary evidence on the division of the land. Rubakhin, however, was adamant that the burden for this unjust decision fell on the native judicial assembly, whose

glaring superficiality turned out to the benefit of the Jalayirs. The assembly had to define the boundaries of the rain-watered land of the Jalayirs according to sharita. This was all they had to do. But they did not follow your order; they did check the document, [but] they did not go to the spot and did not inspect the irrigated land. For reasons unclear to me, they divided the Balghali settlement. Alfalfa fields, two shrines, one mosque, and twenty-two courtyards with buildings and plantations, which belonged to the Balghalis according to uncontested, permanent, and hereditary possession, use and disposal, ${ }^{145}$ were assigned to the Jalayirs

Doznanie, 29.09.1904, ibid.: 1l. 15-20. 


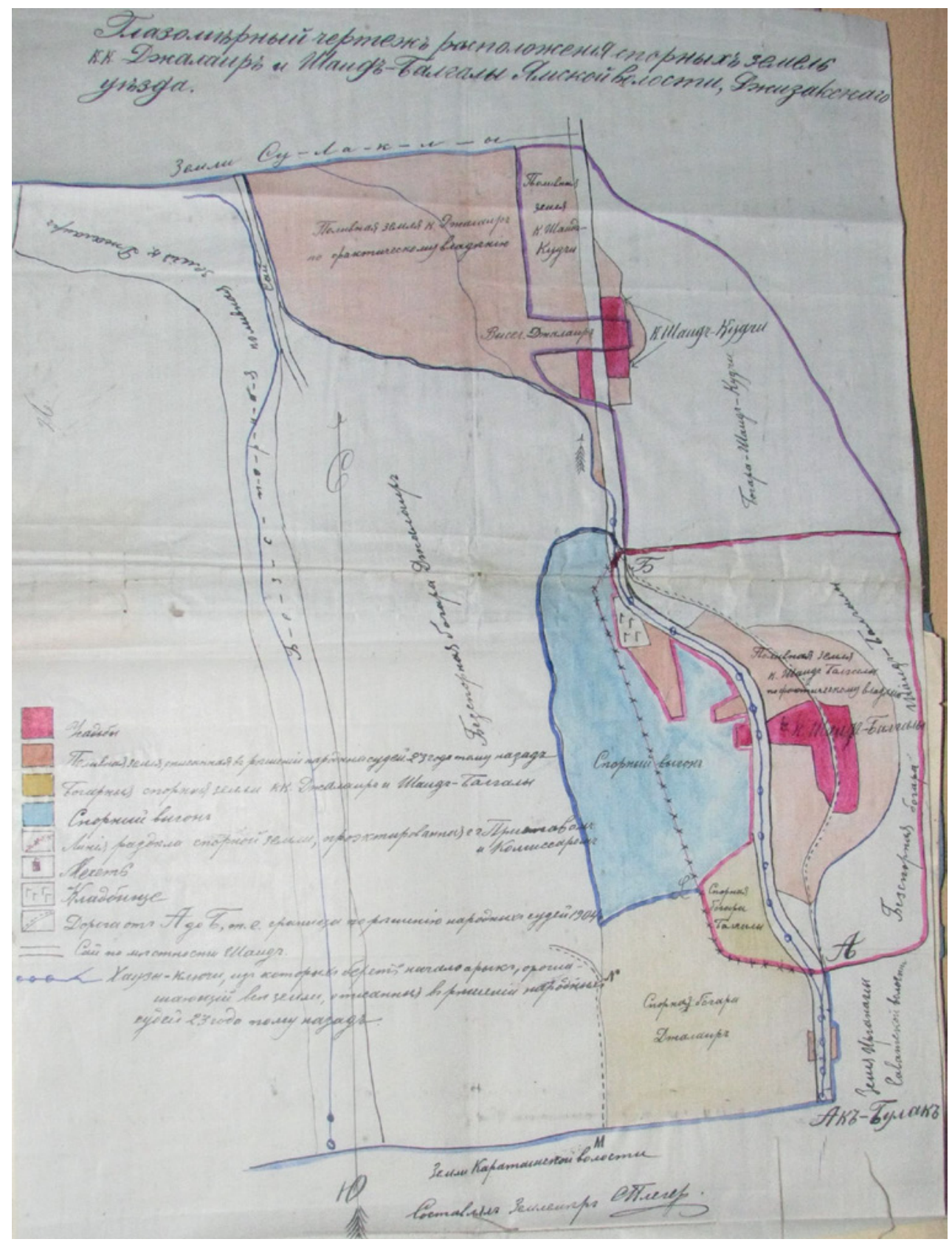

FIGURE 13 Land assessor's map of the contested lands in the Jalayir and Balghali settlements, Iam County, Jizzakh District, 1904, TsGARUz, f. I-21, op. 1, d. 634, l. unnumbered. COURTESY OF THE CENTRAL STATE ARCHIVE OF UZBEKISTAN 
on the basis of only one oath, which was sworn by a few suspicious indigenes, who had no idea whatsoever of what they were swearing. The decision was absolutely unjust, partial, and not in accordance with any rules. I consider it necessary to appeal it and file an action against the judicial assembly $[\ldots]$ for their superficiality, for the intentionally inadequate selection of witnesses, and for their mockery of justice [izdevatel'stvo nad pravosudiem $] \cdot \cdot^{146}$

The impassioned report of Rubakhin provided scant juristic grounds for curtailing the ambitions of Mullā Rustam and his son, but it must have been easy for the Samarqand okrug military court to find arguments to overturn the qädī' judgment. In reviewing the case, the military officials ruled that the native judicial assembly was in breach of the statutory law (Article 211 of the polozhenie) that conferred on native courts the power to hear cases among "physical" entities only, while the military court considered rural communities to be "juridical" entities. The case therefore fell under the jurisdiction of the Russian justices of the peace, and the decision of the native court was quashed. ${ }^{147}$ This time, a certificate of settlement did not prove sufficient to seize marginal lands.

\section{Conclusion}

Russian land policy in Central Asia was centered on the alleged recognition of the existing forms of land tenure. The rationale behind such a policy was simple: reinforcing tenure would guarantee a stable fiscal income. The question of whether imperial agencies regarded such income as sufficient for financing the colonial enterprise in Russian Turkestan and in compliance with policies of resettlement (pereselenie) is of little concern to the present study; readers are directed instead to the excellent studies of Beatrice Penati. ${ }^{148}$

Of greater interest for a legal history of Russian Central Asia is the fact that colonization was conducive to the bureaucratization and subsequent modification of local perceptions of tenure. The purported preservation of indigenous notions of land tenure restricted a complex understanding of property

146 Land-tax commissioner Rubakhin to the Zaamin chief of police (pristav), 01.10.1904, TsGARUz, f. I-21, op. 1, d. 634, ll. 23-23ob.

147 Ruling of the Samarqand okrug court, 26.10.1904 [copy], ibid.: l. 4ob.

148 See especially her "The Cotton Boom and the Land Tax in Russian Turkestan (188os1915)," and "Managing Rural Landscapes in Colonial Turkestan: A View from the Margins." In Explorations into the Social History of Modern Central Asia (19th-2oth Century), ed. P. Sartori (Leiden: Brill, 2013): 65-109. 
relations and transformed it into a narrower, liberal notion of land-ownership. Local sources indicate that, before the Russian conquest, Central Asian rulers, landowners, and tenants viewed land less in terms of property relations than in terms of rent and usufruct. This notion is reflected in Islamic juristic sources and notarial materials in which the legal term milk (property) refers to produce, not to land. Land was not just a commodity that could be exchanged and monetized. Central Asians regarded land mainly in terms of its agricultural produce. Local juristic sources therefore indicate that property rights to land should be made equal to and exchanged for property rights to the produce. In other words, a peasant tilling a plot of land, say, in Marghilan, was not particularly interested in whether the land belonged legally (i.e., formally) to someone living in Tashkent, as long as he was entitled to a share of the produce. In fact, that peasant could sell his proprietary entitlements to the land by claiming to have planted trees or erected a warehouse or a barn, for instance. Hence, Islamic legal deeds tell us that individuals sold and purchased property in the form of improvements (usküna/sukniya) on the land. It is unlikely that a peasant would boast the ownership of a tree, but he must have known that his share of the produce gave him rights to the land. Central Asian fatwas indicate clearly that, because peasants' usufruct generated proprietary rights (tașarruf-i malīkāna), landowners could not easily evict them from peasants' own possessions.

This situation conflicted with what the Russians understood as landownership. As the Russian bureaucracy conferred exclusive probative value on deeds attesting to ownership rights, specifically on arable land, it necessarily disempowered individuals who enjoyed only rights of disposal to communal property and groups traditionally practicing seasonal pastoralism. Groups engaged in seasonal pastoralism rarely kept deeds at hand unless the khan and his chanceries restricted their access to the land with narrow contractual stipulations. In their understanding of land tenure, they had been able to dispose of land that belonged to them from time immemorial. Colonial bureaucracy made things easier, by contrast, for those who could document on paper their rights, either ostensible or actual, to cultivated land. The paperwork of district chanceries suggests that, in such circumstances, a battle for milk unfolded on many fronts. We know that local scrambles for land often ended in amicable settlements, which stipulated that one party pay the other for certain plots of land. It is no coincidence that such exchanges appear to have involved lands that belonged formerly to the treasury of the khanates. It would be hasty to conclude that such turf wars were less authentic than simulated, but it apparently did not take long for locals to understand that the Russian bureaucratic regime had become a valuable new legal resource. 